\title{
Profit Shifting by Debt Financing in Europe
}

\author{
Francesca Barion \\ Raffaele Miniaci \\ Paolo M. Panteghini \\ Maria Laura Parisi
}

CESIFo WORKING PAPER NO. 2985

CAtegory 1: Public Finance

MARCH 2010
An electronic version of the paper may be downloaded
- from the SSRN website: Www.SSRN.com
- from the RePEc website: Www.RePEc.org
- from the CESifo website: www.CESifo-group.org/wp




\title{
Profit Shifting by Debt Financing in Europe
}

\begin{abstract}
This article aims at analyzing the link between subsidiaries' capital structure and taxation in Europe. First we introduce a trade-off model, which studies a MNCs' financial strategy and shows how debt policy allows multinational groups to shift profits from low-tax to high-tax jurisdictions. By letting the MNC choose both leverage and the percentage of profit shifting, we depart from the relevant literature which has mainly focused on the latter. Using the AMADEUS dataset we show that: i) subsidiaries' leverage increases with the statutory tax rate, levied in the country where it operates; ii) this positive effect is lower, the higher the parent company tax rate is. Furthermore, an increase in the parent company's tax rate is estimated to raise its subsidiaries' leverage.
\end{abstract}

JEL-Code: G31, H25, H32.

Keywords: capital structure, default, multinationals, profit shifting, taxation.

Francesca Barion

barionfrancesca@hotmail.com

Paolo M. Panteghini

Faculty of Economics

University of Brescia

Via S. Faustino 74/B

Italy-25122 Brescia

panteghi@eco.unibs.it
Raffaele Miniaci

miniaci@eco.unibs.it

Maria Laura Parisi

parisiml@yahoo.it 


\section{Introduction}

The literature on multinational companies (MNCs) has gathered interesting evidence regarding both financing decisions and their ability to shift income from high- to low-tax jurisdictions. In particular, this evidence shows that income can be shifted by means of debt policies, and that the amount of income shifted depends on tax rate differentials.

Most empirical work on MNCs' choices is based on US and Canadian data. ${ }^{1}$ More recently, however, scholars have focused on tax determinants of European companies' strategy. In particular, Mintz and Weichenrieder (2005), Buettner et al. (2006a, 2006b) and Buettner and Wamser (2007) have analyzed the impact of taxation on German companies. Huizinga et al. (2008) have applied a static model of a multinational firm's optimal profit shifting policy. Using AMADEUS firm-level dataset for European companies, they have shown that their theoretical predictions are supported by the evidence. In particular, a foreign subsidiary's capital structure depends on local corporate tax rates as well as on the difference between its parent company's tax rate and other foreign subsidiaries' rates. However, the effect of taxes on leverage is estimated to be small.

Our article looks at the link between subsidiaries' capital structure and taxation in Europe. We first introduce a dynamic trade-off model that describes a MNCs' financial strategies. In doing so, we can consider default as a contingent event, which depends on the EBIT's volatility as well as on other deep parameters (such as the risk-free interest rate, the EBIT's expected growth). This framework allows us to study the determinants of a MNC's optimal leverage and to understand how debt policy allows multinational groups to shift profits from low-tax to high-tax jurisdictions. In particular, we analyze MNC's choices in terms of both optimal leverage and

\footnotetext{
${ }^{1}$ For instance, Collins and Shackelford (1992) and Froot and Hines (1995) use consolidated financial accounting data from Compustat. They show that firms' financial activities are affected by taxation. Altshuler and Mintz (1995) study the impact of the changes to interest allocation rules in the 1986 tax reform, using the data of large companies. Desai et al. (2004a) use confidential individual data and find that tax rates strongly affect the use of debt by affiliates. Their central estimate is that a $10 \%$ higher tax rate is associated with $2.8 \%$ higher affiliate debt as a proportion of assets. Internal debt is particularly sensitive. Income shifting activities are also been dealt with by Altshuler and Grubert (2003), Desai et al. (2004), Graham and Tucker (2005), Hines (1999), Jon and Tang (2001), Mills and Newberry (2004), Newberry and Dhaliwahl (2001), Mintz (2000) and Mintz and Smart (2004). For further details, see Devereux (2007).
} 
profit shifting, thereby departing from standard models (see, e.g., Huizinga et al., 2008), which usually focuses on profit shifting activities assuming that leverage is exogenously given.

Using the AMADEUS dataset we show that subsidiaries' leverage increases with its host country tax rate and that this positive effect is lower the higher the parent company tax rate is. Moreover, we show that an increase of the parent company's tax rate raises the leverage of its subsidiaries.

The structure of the article is as follows. Section 2 discusses the trade-off model and focuses on the tax determinants of financial choices. Section 3 deals with the AMADEUS dataset and discusses some preliminary evidence on our sample. Section 4 provides an empirical investigation of the determinants of these subsidiaries' financial structure. Section 5 summarizes our findings.

\section{The model}

In this section we introduce a trade-off model describing the financial strategies of a representative MNC resident in country A, and owning a subsidiary located in country B. ${ }^{2}$ Here, we assume that a MNC can borrow from a third-party lender operating in a perfectly competitive sector, which is characterized by a given risk-free interest rate $r$ and by symmetric information. We will let this MNC both choose its optimal leverage (by setting the coupon $C$ ) and decide how much profit to shift from one country to another.

Let us introduce the following assumptions:

Assumption 1 The MNC's EBIT (Earning Before Interest and Taxes), defined as $\Pi(t)$, follows a geometric Brownian motion

$$
\frac{d \Pi(t)}{\Pi(t)}=\mu d t+\sigma d z(t), \text { with } \Pi(0) \geq 0,
$$

where $\mu$ is the expected rate of growth, $\sigma$ is the instantaneous standard deviation of $\frac{d \Pi(t)}{\Pi(t)}$, and $d z(t)$ is the increment of a Wiener process.

Assumption 2 Within the multinational group, the parent company produces a portion $\chi \in(0,1)$ of the overall EBIT; the remaining part $(1-\chi)$ is produced by its foreign subsidiary.

\footnotetext{
${ }^{2}$ This model mainly draws on Panteghini (2009).
} 
Assumption 3 At time 0, the $M N C$ can decide how much to borrow and consequently pays a constant coupon, defined as $C$, for debt finance.

Assumption 4 Debt is divided between the parent company and its subsidiary with weights $\chi$ and $(1-\chi)$, respectively.

Assumption 5 Debt is non-renegotiable and default occurs when the MNC's net cash flow falls to zero.

Assumption 6 The cost of default is $v \in(0,1)$ times the value of the bankrupt $M N C$.

According to assumption 1, a MNC's EBIT evolves stochastically and is jointly produced by the parent company A and the subsidiary B, with weights (see assumption 2) $\chi$ and $(1-\chi)$, respectively. According to assumption 3, the $\mathrm{MNC}$ chooses its leverage ratio by setting a coupon $C{ }^{3}$ For simplicity, assumption 4 states that debt is divided between the parent company and its subsidiary with the same weights assumed for the apportionment of EBIT (i.e., $\chi$ and $(1-\chi)$ ). It is worth noting that the quality of results does not change if, for some non-tax-motivated reason, debt weights are different from the EBIT ones.

As explained by Smith and Warner (1979), if debt renegotiation is costly or even impossible (according to assumption 5$),{ }^{4}$ default may take place. Otherwise, the probability of default would be nil. In our model, default occurs when the MNC's net cash flow falls to zero. ${ }^{5}$ In this event, the MNC is expropriated by the lender, who faces a sunk cost. ${ }^{6}$ In line with Leland (1994), such a cost is assumed to be proportional to the MNC value (assumption 6).

Taxation plays a crucial role in our model. Indeed, with zero tax rates the MNC would have no incentive to borrow. Given these assumptions, debt

\footnotetext{
${ }^{3}$ Given $C$ we can calculate the fair value of debt. For further details on this point see Leland (1994).

${ }^{4}$ For an analysis of costly debt renegotiation see, e.g., Goldstein et al. (2001).

${ }^{5}$ This also implies that debt is secured. As explained by Smith and Warner (1979, p. 127) "[s]ecuring debt gives bondholders title to pledged assets until the bonds are paid in full". As pointed out by Leland (1994), minimum net-worth requirements, implied by secured debt, are more common in short-term debt financing.

${ }^{6}$ For further details on default conditions see Smith and Warner (1979), and Leland (1994). For a study of corporate taxation under default risk see also Panteghini (2006, 2007).
} 
finance might cause costly default with no benefit. However, when taxation is introduced and interest payments are deductible, a tax benefit arises from debt finance. Let us therefore denote $\tau_{A}$ and $\tau_{B}$ as the parent company's statutory corporate tax rate in the home country A and the foreign subsidiary's one in country B, respectively. For simplicity, we also assume that the tax system is fully symmetric (i.e., profit and loss are treated symmetrically) and follows the source principle. ${ }^{7}$ In this case, the MNC finds it optimal to borrow by taking account of both the tax benefit and the expected cost of default. According to assumption 4, debt can be divided between the parent company and its subsidiary.

It is worth noting that, whenever tax rates across countries are different, a MNC has an incentive to shift profit from one entity located in a high-taxrate country to another one operating in a low-tax-rate country. We therefore let the MNC shift profit by means of internal debt financing. In other words, the MNC's entities sign a financial arrangement according to which the entity operating in a high-tax country borrows from the entity placed in the low-tax country. This leads to the payment of an interest which reduces (increases) the reported profit where taxation is high (low). The MNC's overall tax rate is thus reduced.

However, shifting income by means of intra-firm borrowing and lending is costly. The cost of income shifting is due to two main factors: one is related to advising activities and the other is due to anti-avoidance rules. On the one hand, shifting income usually requires the costly advice of tax and financial experts. On the other hand, countries aim to prevent taxavoiding practices by introducing ad hoc rules, such as thin capitalization and Controlled-Foreign-Company (CFC) rules. ${ }^{8}$

Let us therefore assume that the amount of profit shifted is proportional to the coupon, i.e., $\gamma C$ with $\gamma \in[-1,1]$. Denoting $\nu(\gamma, n)$ and $n \in[0, \infty)$ as the concealment cost paid by the MNC and the parameter value, which measures how costly it is for the MNC to shift 1 Euro from one country to the other, respectively, we can write the overall group's after-tax profit function

\footnotetext{
${ }^{7}$ Notice that the existence of deferral possibilities and limited credit rules can de facto lead to the application of the source principle.

${ }^{8}$ For a discussion on the application of these devices in EU countries see Garbarino and Panteghini (2007).
} 
as: ${ }^{9}$

$$
\begin{aligned}
\Pi^{N}(\Pi)= & \left\{\left(1-\tau_{A}\right)[\chi(\Pi-C)-\gamma C]-\nu(\gamma, n) C\right\} \\
& +\left\{\left(1-\tau_{B}\right)[(1-\chi)(\Pi-C)+\gamma C]\right\} \\
\text { subsidiary's after-tax profit } & \\
= & (1-\widehat{\tau})(\Pi-C)+\phi(\gamma, n) C,
\end{aligned}
$$

where $\widehat{\tau} \equiv \chi \tau_{A}+(1-\chi) \tau_{B}$ and $\phi(\gamma, n) \equiv\left[\left(\tau_{A}-\tau_{B}\right) \gamma-\nu(\gamma, n)\right]$ are the MNC's effective tax rate and the net benefit of 1 Euro shifted from a hightax to a low-tax country, respectively. As can be seen, $(1-\widehat{\tau})(\Pi-C)$ is the after-tax profit in the absence of profit shifting. If the MNC undertakes profit shifting activities, the term $\phi(\gamma, n) C$ is added.

In order to obtain a closed-form solution we introduce the following:

Assumption 7 Income shifting entails a quadratic cost function, i.e.,

$$
\nu(\gamma, n)=\frac{n}{2} \gamma^{2}
$$

Parameter $n$ allows us to deal with both institutional determinants and tax and financial advising activities. On the one hand, the introduction of thin capitalization and CFC devices, aiming to prevent tax avoiding activities, raises $n$ and hence, the costs of income shifting. On the other hand, the decrease in the cost of tax sheltering operations, which is linked to the degradation of book and tax profits (see, e.g., Desai, 2003, 2005), leads to a decrease in $n .^{10}$

According to assumption 5, default occurs when $\Pi^{N}(\Pi)$ goes to zero. Therefore, setting (2) equal to zero and then solving for $\Pi$ gives the default threshold point: ${ }^{11}$

$$
\bar{\Pi}=\left[1-\frac{\phi(\gamma, n)}{1-\widehat{\tau}}\right] C=\frac{1-[\widehat{\tau}+\phi(\gamma, n)]}{1-\widehat{\tau}} C=\frac{1-\eta(\gamma, n, \widehat{\tau})}{1-\widehat{\tau}} C,
$$

\footnotetext{
${ }^{9}$ In line with Panteghini and Schjelderup (2006), we also assume that the cost of income shifting is non-deductible. The quality of results would not change if we assumed partial or full deductibility of such costs.

${ }^{10}$ If thus, $n$ goes to zero, the firm can shift profit at no cost: in this case, all the profit is shifted to the lower-tax country. If, instead, $n$ goes to infinity, income shifting is impossible.

${ }^{11}$ The quality of results does not change if we set a different threshold value. For further details on default conditions, see, e.g., Brennan and Schwartz (1977), Smith and Warner (1979), and Leland (1994).
} 
where $\eta(\gamma, n, \widehat{\tau}) \equiv \widehat{\tau}+\phi(\gamma, n)$ is the overall tax benefit of debt finance. Given (4) we can now write the MNC's value (see Appendix A) as:

$V(C, \gamma ; \Pi)=\frac{(1-\widehat{\tau}) \Pi}{\delta}+\frac{\eta(\gamma, n, \widehat{\tau}) C}{r}-\left[\frac{v(1-\widehat{\tau}) \bar{\Pi}}{\delta}+\frac{\eta(\gamma, n, \widehat{\tau}) C}{r}\right]\left(\frac{\Pi}{\bar{\Pi}}\right)^{\beta_{2}}$

where $\delta=r-\mu$ and $\beta_{2}=\frac{1}{2}-\frac{\mu}{\sigma^{2}}-\sqrt{\left(\frac{\mu}{\sigma^{2}}-\frac{1}{2}\right)^{2}+\frac{2 r}{\sigma^{2}}}<0$. As can be seen, function (5) consists of three terms. The first term measures the net present value of the after-tax EBIT. The second term measures the overall net benefit arising from debt financing. The third term measures the expected cost of default. This cost is proportional to the coupon paid. Moreover, it depends both on the tax benefit lost (i.e., $\widehat{\tau}$ ) after default and on the sunk cost of default. The term $\left(\frac{\Pi}{\bar{\Pi}}\right)^{\beta_{2}}$ measures the present value of 1 Euro contingent on the event of default.

\subsection{The MNC's choices}

The MNC can make two tax-motivated decisions. Firstly, it can choose the group's leverage. Secondly, it can decide how much income can be shifted from one country to another. Accordingly, in our model the MNC optimally chooses its overall coupon $\left(C^{*}\right)$ and the percentage of profit shifting $\left(\gamma^{*}\right)$. Given (5), $C^{*}$ and $\gamma^{*}$ are the solutions of the following problem: ${ }^{12}$

$$
\max _{C, \gamma} V(C, \gamma ; \Pi)
$$

Solving (6) we obtain (see Appendix B):

$$
C^{*}=\left\{\frac{1}{1-\beta_{2}} \frac{1}{\frac{v r}{\delta}\left[\frac{1}{\widehat{\tau}+\phi\left(\gamma^{*}, n\right)}-1\right]+1}\right\}^{-\frac{1}{\beta_{2}}}\left(\frac{1-\widehat{\tau}}{1-\left[\widehat{\tau}+\phi\left(\gamma^{*}, n\right)\right]}\right) \Pi
$$

and

$$
\gamma^{*}=\frac{\tau_{A}-\tau_{B}}{n} .
$$

It is worth noting that our model differs from those used in previous articles. For instance, Huizinga et al. (2008) assume an exogenously given

\footnotetext{
${ }^{12}$ The maximization of the MNC's overall value (including debt) implicitly rules out any agency conflict between shareholders and the lender.
} 
leverage ratio $\lambda^{*}$. Deviations of the leverage ratio at any establishment from the level $\lambda^{*}$ are assumed to imply incentive-related costs to the firm. As shown by solutions (7) and (8), however, both the multinational group's leverage (i.e., the coupon) and the optimal percentage of profit shifting are endogenously determined. This means that tax-motivated activities interact one with the other.

As we can be seen in (7), $C^{*}$ is proportional to the current EBIT, $\Pi$. It is also easy to prove that $\frac{\partial C^{*}}{\partial v}<0$; i.e., an increase in the sunk cost of default reduces the propensity to borrow. ${ }^{13}$ It is worth noting that risk affects leverage. ${ }^{14}$ As shown by Leland (1994), the value of debt is a U-shaped function of volatility (i.e., it is increasing up to a certain threshold value of the coupon).

As shown in (8), the optimal percentage of income shifted depends on the corporate income tax rate differential $\left(\tau_{A}-\tau_{B}\right)$. This means that if $\tau_{A}>\tau_{B}$, the firm shifts income from the home to the foreign country and vice versa. Substituting (8) into (26), we obtain the per-unit net tax benefit of income shifting:

$$
\phi\left(\gamma^{*}, n\right)=\frac{\left(\tau_{A}-\tau_{B}\right)^{2}}{2 n} .
$$

This means that a positive tax benefit arises whenever tax rates $\tau_{A}$ and $\tau_{B}$ are different.

Let us next provide some comparative statics on tax determinants. As shown in Appendix C, the derivatives of $C^{*}$ with respect to the MNC's effective tax rate $\widehat{\tau}$ and the net benefit of profit shifting $\phi\left(\gamma^{*}, n\right)$ are (see Appendix C):

$$
\begin{gathered}
\frac{\partial C^{*}}{\partial \widehat{\tau}}>0, \\
\frac{\partial C^{*}}{\partial \phi\left(\gamma^{*}, n\right)}>0 .
\end{gathered}
$$

Given their positive sign, we can say that both the effective tax rate and the net benefit of profit shifting stimulate borrowing, i.e., raise the optimal coupon for a given level of EBIT.

\footnotetext{
${ }^{13}$ A detailed comparative statics analysis is provided by Leland (1994) and Goldstein et al. (2001).

${ }^{14}$ Desai et al. (2004) show that political risk encourages MNCs to use greater debt. Fan et al. (2003) make a cross-country comparison supporting the idea that business risk discourages debt issues.
} 
Let us next calculate the effect of tax rates $\tau_{A}$ and $\tau_{B}$ on the optimal coupon. We obtain:

$$
\begin{aligned}
& \frac{d C^{*}}{d \tau_{A}}=[\underbrace{\frac{\partial C^{*}}{\partial \widehat{\tau}} \frac{\partial \widehat{\tau}}{\partial \tau_{A}}}_{\substack{>0 \\
\text { overall tax rate }}}]+[\underbrace{\frac{\partial C^{*}}{\partial \phi\left(\tau_{A}-\tau_{B}\right)}}_{\begin{array}{c}
>0 \\
\text { profit shifting }
\end{array}}],
\end{aligned}
$$

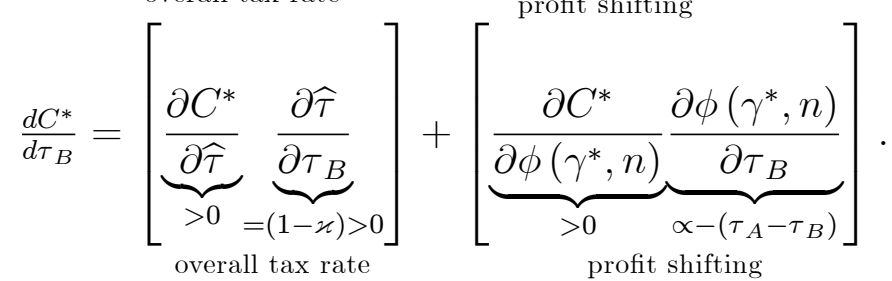

According to our model, the effect of a tax rate change on leverage is twofold. Firstly, an increase (decrease) in $\tau_{i}$ (with $i=A, B$ ) raises (reduces) the MNC's overall tax rate $\widehat{\tau}$. Due to interest deductibility, the tax-rate increase (decrease) raises (reduces) $C^{*}$, thereby stimulating (discouraging) debt finance (see the first term in square brackets on the RHS of derivatives $d C^{*} / d \tau_{i}$, with $\left.i=A, B\right)$. As we have pointed out, this effect is usually disregarded in the relevant literature.

Secondly, the tax rate change affects the tax rate differential $\left(\tau_{A}-\tau_{B}\right)$ and can therefore influence profit shifting activities (see the second term in square brackets on the RHS of derivatives $d C^{*} / d \tau_{i}$, with $i=A, B$ ). It is worth noting that this latter effect is ambiguous: if $\left(\tau_{A}-\tau_{B}\right)>0$, we have $d C^{*} / d \tau_{A}>0$ and $d C^{*} / d \tau_{B} \lessgtr 0$. If however $\left(\tau_{A}-\tau_{B}\right)<0$, we can see that $d C^{*} / d \tau_{A} \lessgtr 0$ and $d C^{*} / d \tau_{B}>0$. The reasoning behind this ambiguity is as follows: if $\left(\tau_{A}-\tau_{B}\right)>0$, an increase in $\tau_{A}$ leads to a higher tax rate differential and therefore stimulates profit shifting. The opposite is true for an increase in $\tau_{B}$. A similar reasoning holds if the tax rate is $\left(\tau_{A}-\tau_{B}\right)<0$.

Given these results, we can therefore say that an increase in the parent company's tax rate $\left(\tau_{A}\right)$ can positively affect a subsidiary's leverage. It is worth noting that the quality of results would not change if we assumed $N \geq 1$ subsidiaries. Again, we would expect a positive effect of the overall tax rate $\widehat{\tau}$ and an ambiguous impact of subsidiaries' tax rates on leverage. This latter effect would depend on the signs of tax rate differentials. 


\subsection{Bringing the model to the data}

In this article, we will use financial statements' data to estimate the sign and size of the tax rate effects. In line with most empirical research, we will focus on stocks, rather than flows. Using our model's notation we will therefore use the subsidiary's leverage ratio, i.e.,

$$
L_{S}(\Pi)=\frac{D_{S}(\Pi)}{V_{S}(\Pi)}=\frac{D_{S}(\Pi)}{E_{S}(\Pi)+D_{S}(\Pi)},
$$

as the dependent variable. According to assumption 4, the value of debt is

$$
D_{S}(\Pi)=(1-\chi) D(\Pi) \text {. }
$$

As shown in Appendix D, the value of equity is equal to

$$
\begin{aligned}
E_{S}(\Pi)= & \left(1-\tau_{B}\right)\left\{(1-\chi)\left[\left(\frac{\Pi}{\delta}-\frac{C^{*}}{r}\right)-\left(\frac{\bar{\Pi}}{\delta}-\frac{C^{*}}{r}\right)\left(\frac{\Pi}{\bar{\Pi}}\right)^{\beta_{2}}\right]\right. \\
& \left.+\left[1-\left(\frac{\Pi}{\bar{\Pi}}\right)^{\beta_{2}}\right] \frac{\gamma^{*} C^{*}}{r}\right\} .
\end{aligned}
$$

It is worth noting that the impact of taxation on the leverage ratio $L_{S}(\Pi)$ usually has the same sign as the impact on coupon $C^{*}$. To see this, we provide a numerical simulation of the optimal coupon and leverage function (11). To do so, we will assume realistic tax rate values, i.e., $0 \leq \tau_{A} \leq 0.5$, $0 \leq \tau_{B} \leq 0.5$. Moreover, in line with line with Dixit and Pindyck (p. 157 and p. 193,$1994 ; 1999)$ we set $r=0.04, \mu=0$ and $\sigma=0.2$. Finally, we set, $\Pi=1, v=1.1, n=2$, and $\chi=0.5$ (i.e., we assume that the parent company and its subsidiary have equal weight). 


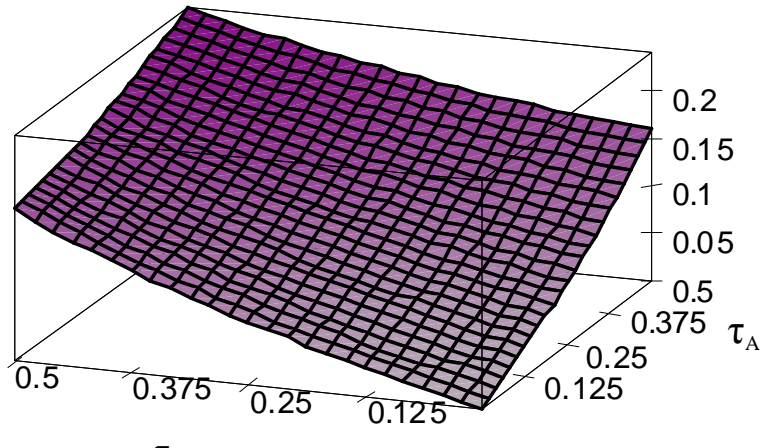

$\tau_{\mathrm{B}}$

Figure 1: Optimal coupon for different values of $\tau_{A}$ and $\tau_{B}$.

Figure 1 shows that MNC's optimal coupon is increasing in both the parent company's tax rate $\tau_{A}$ and the foreign subsidiary one $\tau_{B}$. It is also easy to show that $C^{*}$ is decreasing in $\tau_{A}$, only for unrealistic tax rate values (i.e., $\left.\tau_{A}>0.5\right){ }^{15}$

Figure 2 shows the effects of taxation on a subsidiary's leverage (11). As can be seen, optimal leverage is increasing with both $\tau_{A}$ and $\tau_{B}$. This result supports our idea that an increase in the home-country tax rate $\tau_{A}$ can positively affect a subsidiary's leverage, despite the (negative) profit shifting effect.

\footnotetext{
${ }^{15}$ Data are available upon request.
} 


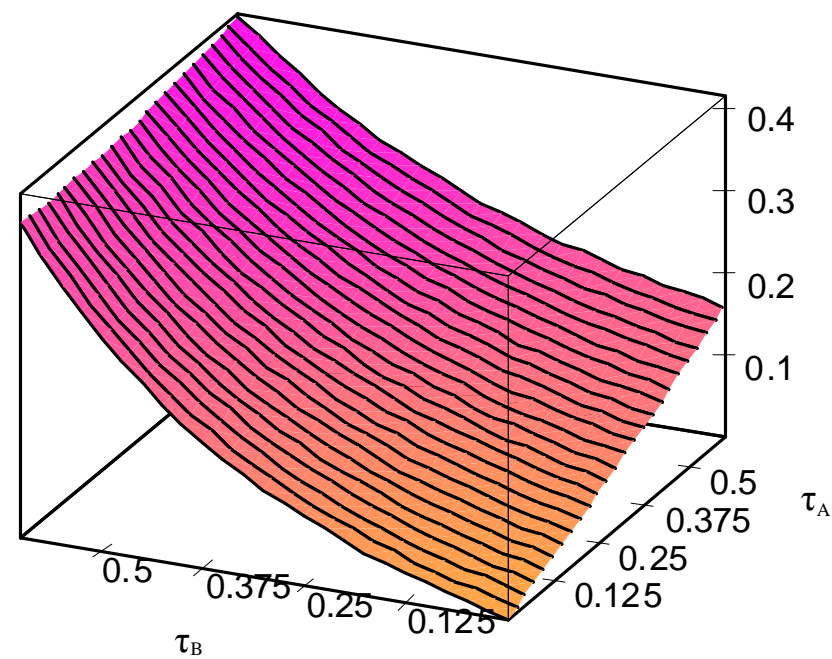

Figure 2: Subsidiary's optimal leverage for different values of $\tau_{A}$ and $\tau_{B}$.

It is worth noting that the quality of results does not change if we use different parameter values. In particular, when the weight $\chi$ is different. Namely, both when the parent company is mostly relevant $(\chi>0.5)$ and when the subsidiary is larger $(\chi<0.5)$, results are similar to those depicted in Figures 1 and 2.

\section{$3 \quad$ Data and preliminary evidence}

The relation between tax schemes and firm capital structure for foreign owned companies can be studied exploiting both the time variation of the national tax rates and the cross-national heterogeneity of their home country tax rates.

A longitudinal data set of companies resident in different countries is provided by the AMADEUS database collected by Bureau van Dijk. This database provides standardized annual balance sheet and profit \& loss items (consolidated and unconsolidated), for up to 1.6 million companies from 38 
European countries (for up to 14 years), together with information on the country where firms are located, their legal form and ownership structure. In order to be included in the database, companies must satisfy at least one of the following criteria: i) more than 100 employees; ii) operating revenues of at least 10 million euros; iii) total assets of at least 20 million euros.

Despite the effort made by Bureau van Dijk to standardize balance sheet and profits \& loss items of different countries, accounting practices are so heterogeneous that differences in the interpretation of firms' financial data across countries still persist. Furthermore, linking subsidiaries and owners accounting data may induce a non-random selection problem in the sample for at least two reasons: (i) we do not have access to accounting data for non-European companies, and (ii) the coverage of the AMADEUS database varies across countries and company types. We therefore provide two sets of estimates, the first for the complete sample of subsidiaries, and a second one for the subsample of subsidiaries we are able to link with the accounting data of their ultimate owners.

We focus on limited companies and limited liability companies, ${ }^{16}$ resident in Belgium, Denmark, Spain, France, Great Britain, Italy, Netherlands, Norway, Portugal, and Sweden whose ultimate owner is resident abroad in a known country and it is not an individual or a family. We define the ultimate owner as the company which directly or indirectly possesses at least $50 \%$ of the shares of a subsidiary. We decide for a high share of ownership because a parent company with a lower level of (direct or indirect) ownership may not be able to affect debt policy' choices (Mintz and Weichenrieder, 2005). Finally, as information on ownership refers to 2005, we keep only those companies whose 2005 accounting data are available for at least 3 consecutive years. We explored the possibility to use information on the subsidiaries located in Germany, Luxembourg, Slovakia and Switzerland, but due to the limited coverage of the AMADEUS database for these countries and the sample selection criteria adopted, the contribution of these countries in terms of additional firms was extremely poor (at most 90 firms per country), and hence, decided to drop them from the sample considered. We have therefore obtained panel data for 12301 subsidiaries controlled by foreign companies.

\footnotetext{
${ }^{16}$ From Amadeus Internet Guide: "Limited Companies: companies whose capital is divided into shares which can be offered to the general public and whose members are only liable for its debts to the extent of any amount unpaid on their shares; Limited Liability Companies: companies whose capital is divided into shares which cannot be offered to the general public. The liability of its members is limited to the amount of their shares."
} 
The number of available observations per each firm varies across countries (see Table 1), going from the average of 2 for Denmark to 6.3 years for France.

The empirical literature on tax-motivated debt finance uses book data rather than mark-to-market values. We also follow the practice, which is dictated by the dataset AMADEUS, that contains the financial reports of both listed and non-listed companies. Only for the former companies, are book and mark-to-market values likely to be close, due to the application of international accounting principles (IAS/IFRS). As to non-listed companies (that is, a large majority), instead, accounting principles may allow us to reckon historical rather than fair values. In this case, the book value of one item may differ from the fair value.

Table 1 shows the 2005 median values of the main balance sheet items conditional on the residence country. As the population of firms is typically composed by many small-medium size companies and few large ones, we prefer to refer to median values to summarize the characteristics of our sample (in many cases the average of the variable falls well above the $75^{\text {th }}$ percentile).

Table 2 reports some financial ratios: the leverage, the return on assets (ROA), the share of fixed assets over total assets, and the Z-score.

We calculate the $Z$-score with the weights proposed in the literature (see Altman, 2002):

$$
Z-\text { score }=6.56 x_{1}+3.26 x_{2}+6.72 x_{3}+1.05 x_{4},
$$

where $x_{1}$ is the ratio between working capital and total assets, $x_{2}$ is the variation of the "other shareholders funds" over total assets, $x_{3}$ is the ratio between EBIT and total assets, and

$$
x_{4}=\frac{\text { shareholders funds }}{\text { non current liabilities }+ \text { current liabilities }} .
$$

In line with most research (see, e.g., Altshuler and Grubert, 2003, Desai et al., 2003, Jog and Tang, 2001, and Mintz, 2000), leverage is given by the ratio between debt (long- and short-term liabilities, excluded commercial debt) and total assets.

The striking heterogeneity shown in Tables 1 and 2 highlights the actual differences in the companies' size, together with the variety of accounting and disclosure obligations and practices. All these factors must be considered when comparing, for instance, the median value for the total assets of the 802 Norvegian subsidiaries (4.5 mil. Euro) with the corresponding value 


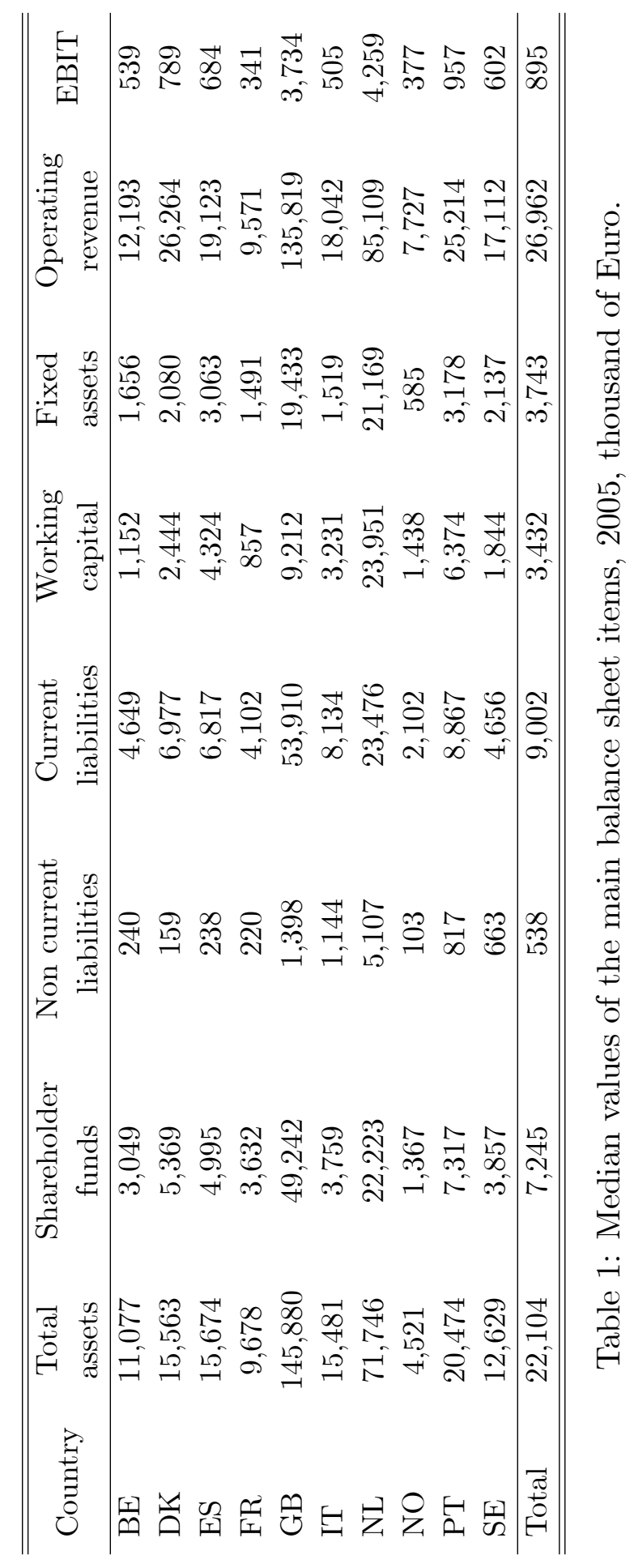




\begin{tabular}{lccccccc}
\hline \hline Country & Leverage & ROA & $\frac{\text { Fixed Assets }}{\text { Total Assets }}$ & Z-score & $\begin{array}{c}\text { Limited } \\
\text { companies }\end{array}$ & $\begin{array}{c}\text { Years } \\
\text { available }\end{array}$ & $\begin{array}{c}\text { Number } \\
\text { of firms }\end{array}$ \\
\hline BE & $67.0 \%$ & $5.7 \%$ & $19.1 \%$ & 2.85 & $9.6 \%$ & 6.1 & 1347 \\
DK & $62.8 \%$ & $8.1 \%$ & $17.3 \%$ & 3.55 & $87.2 \%$ & 2.0 & 572 \\
ES & $63.0 \%$ & $5.8 \%$ & $24.6 \%$ & 4.38 & $70.9 \%$ & 5.3 & 1754 \\
FR & $59.7 \%$ & $5.4 \%$ & $17.9 \%$ & 2.91 & $64.2 \%$ & 6.3 & 1172 \\
GB & $54.7 \%$ & $6.1 \%$ & $14.4 \%$ & 3.37 & $3.2 \%$ & 6.6 & 3442 \\
IT & $74.8 \%$ & $4.9 \%$ & $12.5 \%$ & 3.17 & $47.2 \%$ & 4.4 & 1467 \\
NL & $61.8 \%$ & $7.3 \%$ & $33.7 \%$ & 4.59 & $9.8 \%$ & 5.3 & 529 \\
NO & $70.0 \%$ & $9.9 \%$ & $13.0 \%$ & 4.59 & $0.1 \%$ & 6.1 & 802 \\
PT & $56.9 \%$ & $5.0 \%$ & $25.7 \%$ & 3.90 & $65.2 \%$ & 5.8 & 155 \\
SE & $66.8 \%$ & $5.9 \%$ & $23.5 \%$ & 3.30 & $2.0 \%$ & 6.0 & 1061 \\
\hline Total & $63.5 \%$ & $6.1 \%$ & $17.9 \%$ & 3.53 & $29.3 \%$ & 5.7 & 12301 \\
\hline \hline
\end{tabular}

Table 2: Median value for leverage, ROA, fixed to total assets ratio and Zscore, percentage of limited companies in 2005, average number of years for which data are available, and total number of firms in the sample.

of the 3442 British companies (146 mil. Euro), or the median earnings before interest and taxation (EBIT) of the 529 Dutch firms (4.3 mil. Euro) with those of the 1172 French subsidiaries considered (only 341 thousand Euro). Such differences are somehow reduced when we look at the financial ratios: the median leverage ranges between $55 \%$ for the British subsidiaries and $75 \%$ of the Italian ones, the ROA goes from a minimum of $4.9 \%$ for the Italian companies to $9.9 \%$ of the Norwegian ones. The British subsidiaries account for $28 \%$ of the overall sample, followed by Spanish (14\%), Italian (12\%), Belgian (11\%) and French (10\%). When we complement the subsidiaries' data with the balance sheets of their ultimate owners we automatically drop all subsidiaries, whose parent company is located in the US, Japan and other non-European countries, from the sample. We are able to recover the accounting data of the ultimate owner for about $74 \%$ of the 8421 remaining (European owned) subsidiaries. The nationality mix of the resulting sample is remarkably different from the original one: the share of British subsidiaries drops to $18 \%$, the Spanish firms account for $16 \%$ of the sample, $15 \%$ are Belgian and $12 \%$ Swedish.

Table 3 presents the descriptive statistics of the linked companies: these firms are typically smaller but of comparable profitability and credit wor- 


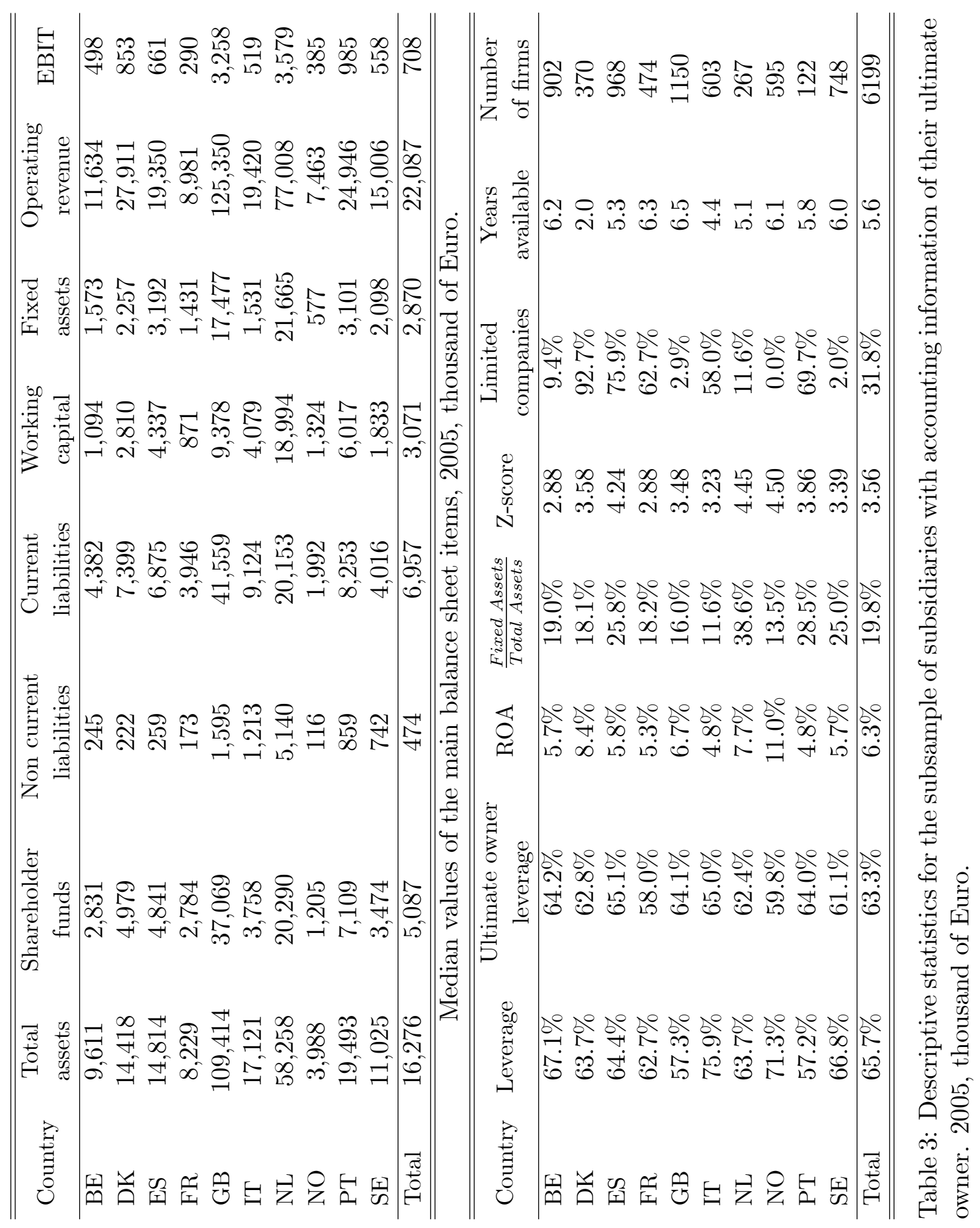


thiness. The subsidiaries' median leverage is usually higher than their ultimate owner's one (with the largest differences in Italy, Norway, Sweden and France), while the converse is true for Great Britain and Portugal, where ultimate owners have a higher median leverage (64\% vs. $57 \%$ of their subsidiaries).

In this article, we will use statutory corporation tax rates. In doing so, we depart from Huizinga et al. (2008), who use effective tax rates (accounting for withholding taxes levied on international transactions) on both crossborder dividends and interest payments. Of course, their approach would be necessary if: i) profit was always distributed to the parent company; ii) no other intra-group transaction would be made (apart from interest payments); iii) high withholding tax rates were levied. However, we know that $100 \%$ of subsidiary's profit is not necessarily distributed: at least a portion of it can be retained abroad. Apart from dividends, there are many other kinds of intragroup transactions (e.g., royalties and commission fees paid by one entity to another inside the same group). Since we have no information on intra-group transactions and the withholding tax rates in the countries of our sample are low (or even zero), we prefer to focus on statutory tax rates.

When we study the relation between taxation and leverage, as well as its variation across countries and over time, we also need to control for the business cycle.

Figure 3 shows the statutory tax rate of the subsidiaries (right-hand axis) together with the growth rate of the per capita gross domestic product based on purchasing-power-parity (PPP) (source: IMF, left-hand axis). The information about statutory tax rates is drawn from KPMG's Corporate Tax Rate Survey (available at the site www.kpmg.com). In the time interval considered, the corporate income tax rate remained constant at $28 \%$ in Norway and Sweden, at 35\% in Spain, and to 30\% since 1999 in Great Britain. The tax rate changed only once in Belgium (from $40 \%$ to $34 \%$ in 2003) and Denmark (from $30 \%$ to $28 \%$ in 2005) and more frequently in other countries. Belgium, France, Italy and Portugal are the countries that cut the tax rates the most, and they mainly did it during periods of slow down of the GDP growth rate. Figure 3 makes it clear that we cannot rely only on time dimension to identify the effect of changes in the subsidiary tax rate on subsidiary's capital structure.

In Figure 4, we plot the time series of the statutory tax rates of the ultimate owners resident in 15 different countries, which is the (almost) complete set of nationalities of the ultimate owners of the subsidiaries we consider. 


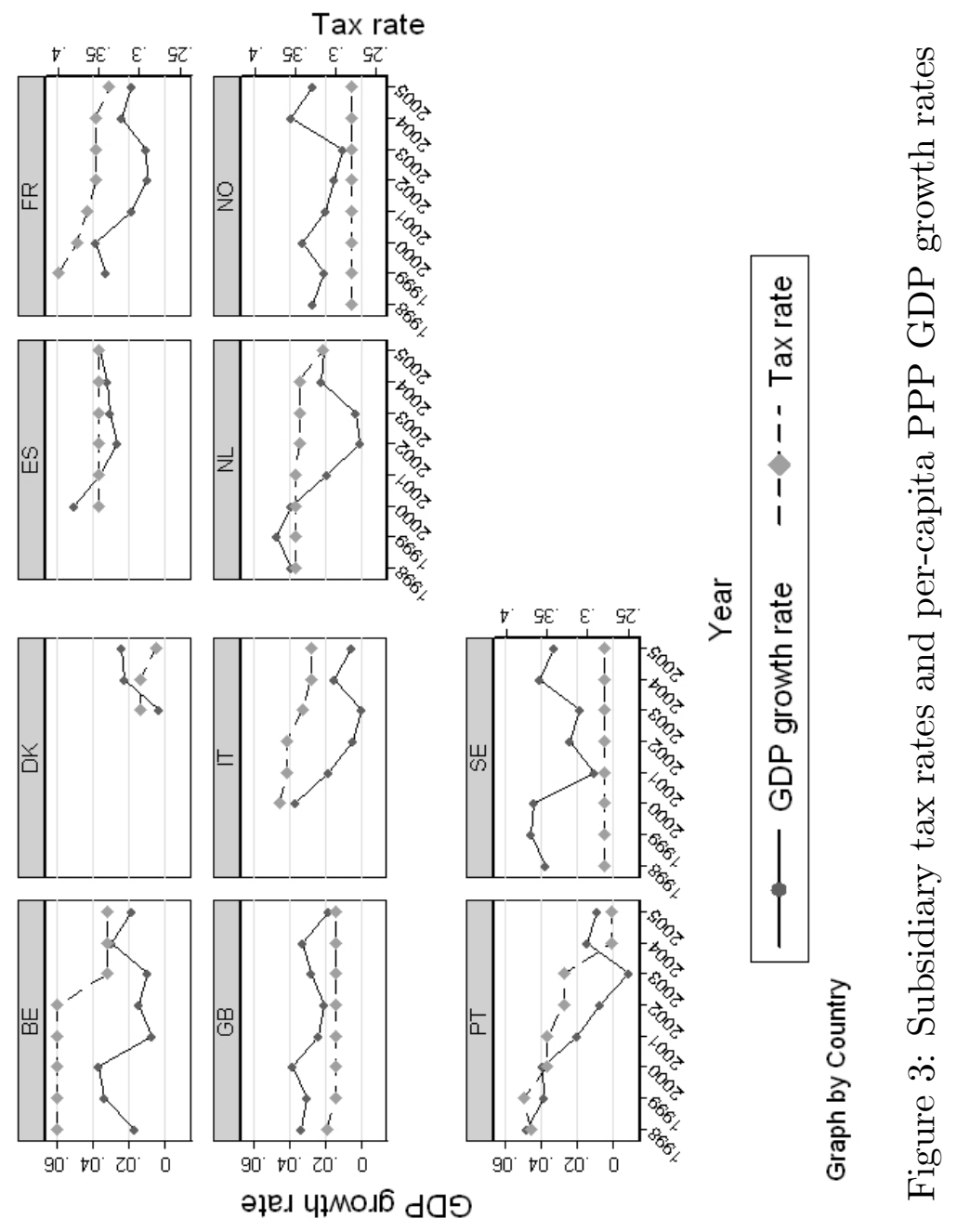




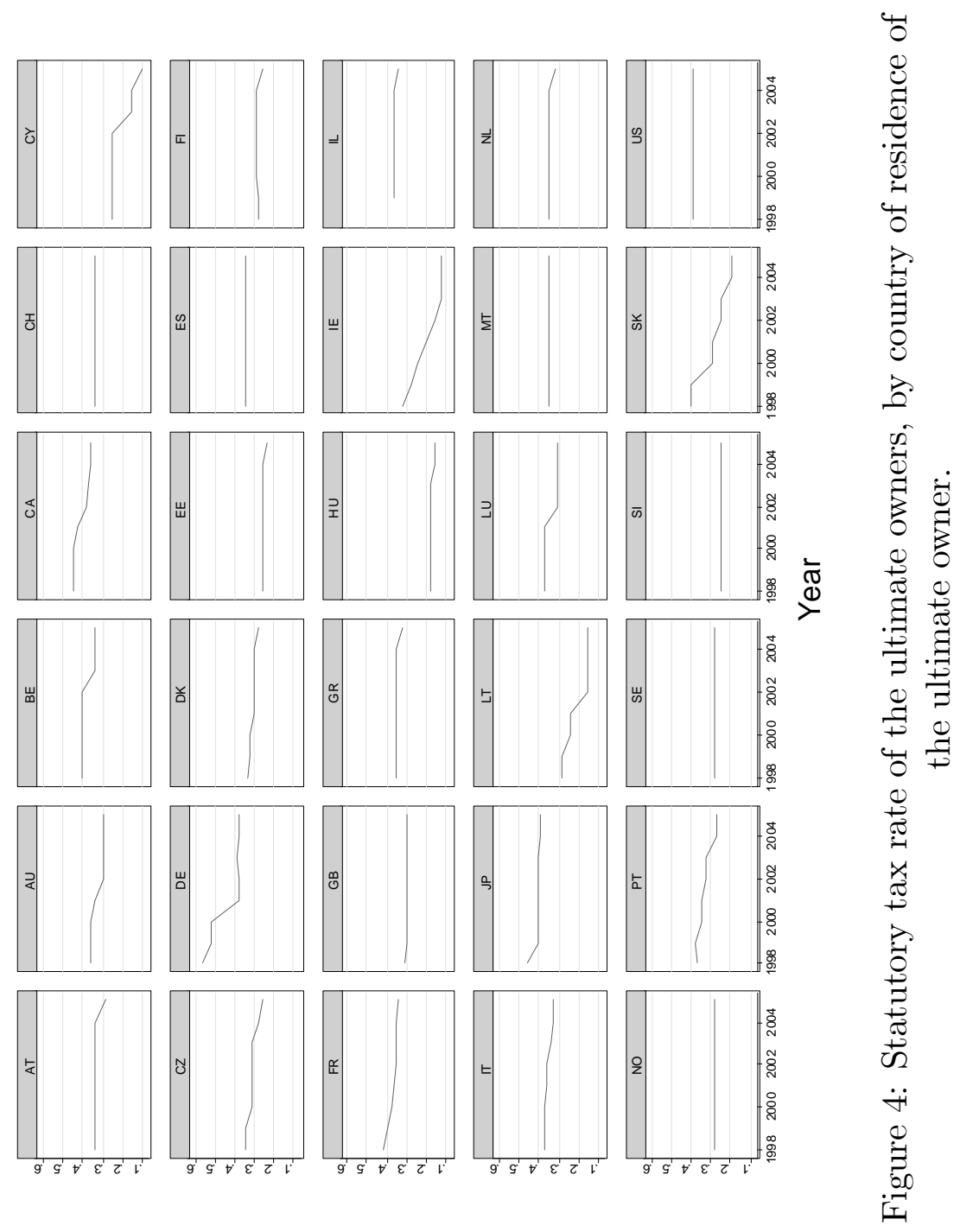


Again, substantial time variation of the tax rates is limited to few countries (e.g., Germany, Ireland, Slovakia and Lithuania), while there is no variation at all for others (e.g., United States, Switzerland, Norway and Sweden). As a consequence, there is little time variation of the home (parent) - foreign (subsidiary) country tax differentials $\left(\tau_{A}-\tau_{B}\right)$. To appreciate which of these differentials are mostly relevant for our analysis it is useful to note that United States, Germany and France are the countries of residence for $47 \%$ of the ultimate owner we consider (see Table 4) and the operating revenues of their subsidiaries account for about $52 \%$ of the cumulated revenues of the companies in the sample. US companies almost always play a significant role as ultimate owners, but still Scandinavian subsidiaries tend to be owned by other Scandinavian companies, as well as Belgian subsidiaries are likely to be

owned by German, French or Dutch companies. If we analyze the relevance of the ultimate owners' countries in terms of cumulated revenues, rather than in terms of number of companies controlled, the United States and Japan play a more important role, while that of France and of the Scandinavian countries is reduced.

In Table 5 we show the average of the foreign-home tax differential $\left(\tau_{B}-\tau_{A}\right)$, that is the average of the difference between the statutory tax rate of the subsidiary and that of the parent company. We first calculate the simple average of these differences and then the weighted average, where each subsidiary's contribution to the mean is proportional to its operating revenue. For each country the average of the first available year is not informative because of the few number of observations in the cell. As we can see, apart from Belgian subsidiaries between 2000 and 2002, parent companies usually face a statutory tax rate which is higher than the subsidiary's one. This may suggest that parent companies prefer to locate subsidiaries in low-tax countries.

\section{Regression analysis}

In order to study the effect of taxation leverage decisions, we implement a multivariate regression analysis. We consider a specification of the regression equation, which combines information from past financial accounts of the companies $\left(F_{i t-1}\right)$ with business cycle and fiscal data $\left(B_{t}\right.$ and $T_{i t}$, respectively): 


\begin{tabular}{|c|c|c|c|c|c|c|c|c|c|c|c|}
\hline \multicolumn{12}{|c|}{ Subsidiary country of residence } \\
\hline & $\mathrm{BE}$ & D K & ES & FR & GB & IT & NL & NO & $\mathrm{PT}$ & $\mathrm{SE}$ & Total \\
\hline $\mathrm{BE}$ & $0.0 \%$ & $1.4 \%$ & $2.6 \%$ & $8.8 \%$ & $1.9 \%$ & $4.8 \%$ & $5.5 \%$ & $0.9 \%$ & $3.2 \%$ & $1.1 \%$ & $2.8 \%$ \\
\hline B M & $0.7 \%$ & $0.5 \%$ & $1.0 \%$ & $1.6 \%$ & $2.1 \%$ & $1.4 \%$ & $2.6 \%$ & $1.0 \%$ & $0.6 \%$ & $0.8 \%$ & $1.4 \%$ \\
\hline $\mathrm{CH}$ & $4.0 \%$ & $4.2 \%$ & $4.5 \%$ & $7.4 \%$ & $5.4 \%$ & $7.7 \%$ & $4.9 \%$ & $3.4 \%$ & $3.9 \%$ & $5.7 \%$ & $5.4 \%$ \\
\hline $\mathrm{DE}$ & $10.6 \%$ & $9.6 \%$ & $15.6 \%$ & $10.5 \%$ & $9.9 \%$ & $11.8 \%$ & $11.9 \%$ & $5.6 \%$ & $12.3 \%$ & $7.9 \%$ & $10.7 \%$ \\
\hline D K & $2.1 \%$ & $0.0 \%$ & $1.2 \%$ & $2.4 \%$ & $1.9 \%$ & $2.0 \%$ & $3.0 \%$ & $10.1 \%$ & $0.6 \%$ & $11.8 \%$ & $3.2 \%$ \\
\hline ES & $0.7 \%$ & $0.2 \%$ & $0.0 \%$ & $3.2 \%$ & $1.6 \%$ & $3.9 \%$ & $0.8 \%$ & $0.2 \%$ & $23.2 \%$ & $0.3 \%$ & $1.7 \%$ \\
\hline FI & $1.0 \%$ & $4.2 \%$ & $0.6 \%$ & $0.4 \%$ & $1.2 \%$ & $0.7 \%$ & $1.7 \%$ & $4.5 \%$ & $1.3 \%$ & $13.4 \%$ & $2.4 \%$ \\
\hline FR & $23.8 \%$ & $5.8 \%$ & $19.2 \%$ & $0.0 \%$ & $11.3 \%$ & $18.5 \%$ & $9.5 \%$ & $5.2 \%$ & $21.9 \%$ & $10.2 \%$ & $12.9 \%$ \\
\hline GB & $7.3 \%$ & $7.5 \%$ & $9.7 \%$ & $11.6 \%$ & $0.0 \%$ & $5.7 \%$ & $10.0 \%$ & $6.1 \%$ & $3.2 \%$ & $7.2 \%$ & $5.8 \%$ \\
\hline $\mathrm{IE}$ & $0.4 \%$ & $0.2 \%$ & $1.3 \%$ & $0.5 \%$ & $3.3 \%$ & $0.1 \%$ & $0.0 \%$ & $0.2 \%$ & $0.0 \%$ & $0.6 \%$ & $1.3 \%$ \\
\hline IT & $2.1 \%$ & $1.2 \%$ & $6.8 \%$ & $5.5 \%$ & $2.3 \%$ & $0.0 \%$ & $4.3 \%$ & $0.2 \%$ & $7.1 \%$ & $0.8 \%$ & $2.8 \%$ \\
\hline $\mathrm{JP}$ & $3.6 \%$ & $2.6 \%$ & $4.4 \%$ & $5.3 \%$ & $7.5 \%$ & $2.2 \%$ & $11.3 \%$ & $1.2 \%$ & $2.6 \%$ & $2.2 \%$ & $4.8 \%$ \\
\hline $\mathrm{LU}$ & $3.1 \%$ & $0.3 \%$ & $0.9 \%$ & $0.7 \%$ & $3.5 \%$ & $2.2 \%$ & $0.8 \%$ & $0.5 \%$ & $2.6 \%$ & $1.2 \%$ & $2.0 \%$ \\
\hline $\mathrm{NL}$ & $13.1 \%$ & $5.8 \%$ & $7.5 \%$ & $8.2 \%$ & $5.5 \%$ & $9.7 \%$ & $0.0 \%$ & $5.4 \%$ & $3.2 \%$ & $6.4 \%$ & $7.2 \%$ \\
\hline $\mathrm{NO}$ & $0.8 \%$ & $6.1 \%$ & $0.7 \%$ & $0.4 \%$ & $1.0 \%$ & $0.3 \%$ & $1.7 \%$ & $0.0 \%$ & $0.0 \%$ & $10.7 \%$ & $1.8 \%$ \\
\hline $\mathrm{SE}$ & $5.7 \%$ & $28.0 \%$ & $3.8 \%$ & $2.4 \%$ & $3.6 \%$ & $4.0 \%$ & $4.0 \%$ & $41.1 \%$ & $3.2 \%$ & $0.0 \%$ & $7.1 \%$ \\
\hline US & $18.6 \%$ & $21.3 \%$ & $15.8 \%$ & $28.2 \%$ & $32.8 \%$ & $22.8 \%$ & $25.0 \%$ & $13.3 \%$ & $10.3 \%$ & $17.3 \%$ & $23.4 \%$ \\
\hline
\end{tabular}

Percentage of subsidiaries by country of residence of their ultimate owner (rows).

Percentages do not sum up to $100 \%$ by column because less relevant countries have been omitted

\begin{tabular}{|c|c|c|c|c|c|c|c|c|c|c|c|}
\hline \multicolumn{12}{|c|}{ Subsidiary country of residence } \\
\hline & $\mathrm{BE}$ & DK & ES & $\mathrm{FR}$ & GB & IT & NL & $\mathrm{NO}$ & $\mathrm{PT}$ & $\mathrm{SE}$ & Total \\
\hline $\mathrm{AU}$ & $0.1 \%$ & $0.2 \%$ & $0.6 \%$ & $0.4 \%$ & $1.1 \%$ & $0.1 \%$ & $0.0 \%$ & $0.0 \%$ & $0.1 \%$ & $0.1 \%$ & $1.0 \%$ \\
\hline $\mathrm{BE}$ & $0.0 \%$ & $0.3 \%$ & $1.7 \%$ & $4.6 \%$ & $2.1 \%$ & $2.8 \%$ & $1.1 \%$ & $0.1 \%$ & $0.3 \%$ & $0.1 \%$ & $2.0 \%$ \\
\hline $\mathrm{BM}$ & $0.5 \%$ & $0.1 \%$ & $1.5 \%$ & $0.6 \%$ & $2.1 \%$ & $1.5 \%$ & $1.9 \%$ & $0.8 \%$ & $0.7 \%$ & $0.1 \%$ & $2.0 \%$ \\
\hline $\mathrm{CA}$ & $0.1 \%$ & $0.0 \%$ & $0.3 \%$ & $1.5 \%$ & $1.8 \%$ & $0.0 \%$ & $0.0 \%$ & $0.0 \%$ & $0.0 \%$ & $0.0 \%$ & $1.6 \%$ \\
\hline $\mathrm{CH}$ & $4.1 \%$ & $2.8 \%$ & $5.5 \%$ & $4.8 \%$ & $7.0 \%$ & $6.4 \%$ & $1.4 \%$ & $2.1 \%$ & $2.1 \%$ & $2.5 \%$ & $6.6 \%$ \\
\hline $\mathrm{DE}$ & $11.3 \%$ & $10.0 \%$ & $14.4 \%$ & $7.3 \%$ & $10.4 \%$ & $16.0 \%$ & $5.6 \%$ & $3.9 \%$ & $19.3 \%$ & $7.5 \%$ & $10.4 \%$ \\
\hline D K & $4.7 \%$ & $0.0 \%$ & $0.7 \%$ & $0.9 \%$ & $2.1 \%$ & $0.5 \%$ & $1.3 \%$ & $4.0 \%$ & $0.4 \%$ & $4.8 \%$ & $2.1 \%$ \\
\hline ES & $0.4 \%$ & $0.0 \%$ & $0.0 \%$ & $5.3 \%$ & $1.4 \%$ & $1.3 \%$ & $0.5 \%$ & $0.1 \%$ & $27.9 \%$ & $0.2 \%$ & $1.4 \%$ \\
\hline FI & $0.9 \%$ & $2.6 \%$ & $0.7 \%$ & $0.2 \%$ & $1.3 \%$ & $0.5 \%$ & $1.0 \%$ & $1.7 \%$ & $1.3 \%$ & $13.0 \%$ & $1.4 \%$ \\
\hline $\mathrm{FR}$ & $20.1 \%$ & $3.8 \%$ & $21.3 \%$ & $0.0 \%$ & $9.5 \%$ & $21.2 \%$ & $8.8 \%$ & $14.5 \%$ & $24.2 \%$ & $4.4 \%$ & $9.8 \%$ \\
\hline GB & $10.7 \%$ & $10.5 \%$ & $6.3 \%$ & $5.4 \%$ & $0.0 \%$ & $8.0 \%$ & $21.2 \%$ & $15.2 \%$ & $2.7 \%$ & $10.7 \%$ & $1.2 \%$ \\
\hline $\mathrm{IE}$ & $0.1 \%$ & $0.4 \%$ & $0.3 \%$ & $0.1 \%$ & $2.9 \%$ & $0.0 \%$ & $0.0 \%$ & $0.0 \%$ & $0.0 \%$ & $0.4 \%$ & $2.6 \%$ \\
\hline IT & $1.4 \%$ & $2.1 \%$ & $4.7 \%$ & $5.0 \%$ & $2.7 \%$ & $0.0 \%$ & $5.0 \%$ & $3.8 \%$ & $3.4 \%$ & $0.1 \%$ & $2.8 \%$ \\
\hline $\mathrm{JP}$ & $6.5 \%$ & $2.8 \%$ & $5.1 \%$ & $6.0 \%$ & $9.1 \%$ & $2.5 \%$ & $16.6 \%$ & $0.7 \%$ & $2.0 \%$ & $4.3 \%$ & $8.9 \%$ \\
\hline $\mathrm{LU}$ & $2.6 \%$ & $0.3 \%$ & $0.6 \%$ & $0.4 \%$ & $3.0 \%$ & $2.5 \%$ & $0.3 \%$ & $0.1 \%$ & $0.6 \%$ & $0.4 \%$ & $2.8 \%$ \\
\hline $\mathrm{NL}$ & $10.9 \%$ & $3.1 \%$ & $9.3 \%$ & $10.1 \%$ & $4.8 \%$ & $9.0 \%$ & $0.0 \%$ & $5.0 \%$ & $1.6 \%$ & $8.0 \%$ & $4.9 \%$ \\
\hline NO & $0.3 \%$ & $9.7 \%$ & $0.3 \%$ & $0.2 \%$ & $1.0 \%$ & $0.1 \%$ & $0.5 \%$ & $0.0 \%$ & $0.0 \%$ & $5.2 \%$ & $1.1 \%$ \\
\hline $\mathrm{SE}$ & $2.9 \%$ & $28.8 \%$ & $3.0 \%$ & $0.5 \%$ & $4.6 \%$ & $4.9 \%$ & $1.0 \%$ & $13.9 \%$ & $2.9 \%$ & $0.0 \%$ & $4.5 \%$ \\
\hline US & $21.8 \%$ & $22.0 \%$ & $22.3 \%$ & $46.2 \%$ & $31.7 \%$ & $22.2 \%$ & $32.3 \%$ & $34.0 \%$ & $10.4 \%$ & $37.5 \%$ & $31.5 \%$ \\
\hline
\end{tabular}

Percentage of cumulated operating revenues by country of residence of the ultimate owner.

Percentages do not sum up to $100 \%$ by column because less relevant countries have been omitted

Table 4: Relevance of the home countries by foreign country. 


\begin{tabular}{rrrrrrrrrrr}
\hline & \multicolumn{8}{c}{ Subsidiary country of residence } \\
Year & BE & DK & ES & FR & GB & IT & NL & NO & PT & SE \\
\hline 1998 & $-1.2 \%$ & & & & $-8.7 \%$ & & $-3.9 \%$ & $3.8 \%$ & $-2.1 \%$ & $-8.1 \%$ \\
1999 & $2.2 \%$ & & & $2.6 \%$ & $-8.0 \%$ & & $-2.5 \%$ & $-4.7 \%$ & $-0.7 \%$ & $-7.4 \%$ \\
2000 & $2.8 \%$ & & $-3.2 \%$ & $0.4 \%$ & $-7.8 \%$ & $-0.2 \%$ & $-2.5 \%$ & $-4.5 \%$ & $-3.2 \%$ & $-7.0 \%$ \\
2001 & $4.7 \%$ & & $-0.6 \%$ & $0.7 \%$ & $-6.0 \%$ & $0.2 \%$ & $-1.1 \%$ & $-3.6 \%$ & $-0.7 \%$ & $-5.5 \%$ \\
2002 & $5.3 \%$ & & $-0.1 \%$ & $-0.2 \%$ & $-5.3 \%$ & $0.8 \%$ & $-1.5 \%$ & $-3.5 \%$ & $-2.3 \%$ & $-5.3 \%$ \\
2003 & $-1.0 \%$ & $-5.8 \%$ & $0.1 \%$ & $0.3 \%$ & $-5.1 \%$ & $-1.1 \%$ & $-0.9 \%$ & $-3.5 \%$ & $-2.2 \%$ & $-5.2 \%$ \\
2004 & $-0.8 \%$ & $-3.0 \%$ & $0.6 \%$ & $0.6 \%$ & $-4.8 \%$ & $-2.0 \%$ & $-0.2 \%$ & $-3.4 \%$ & $-7.9 \%$ & $-5.0 \%$ \\
2005 & $0.1 \%$ & $-4.5 \%$ & $1.2 \%$ & $-0.6 \%$ & $-4.3 \%$ & $-1.2 \%$ & $-2.8 \%$ & $-2.7 \%$ & $-7.4 \%$ & $-3.9 \%$ \\
\hline
\end{tabular}

Average of the foreign - home tax differential

\begin{tabular}{rrrrrrrrrrr}
\hline & \multicolumn{10}{c}{ Subsidiary country of residence } \\
Year & BE & DK & ES & FR & GB & IT & NL & NO & PT & SE \\
\hline 1998 & $-4.9 \%$ & & & & $-9.4 \%$ & & $-5.5 \%$ & $9.6 \%$ & $7.3 \%$ & $-8.0 \%$ \\
1999 & $1.7 \%$ & & & $1.4 \%$ & $-8.6 \%$ & & $-2.7 \%$ & $-7.6 \%$ & $-1.8 \%$ & $-8.4 \%$ \\
2000 & $2.4 \%$ & & $-3.1 \%$ & $-0.7 \%$ & $-8.2 \%$ & $-1.2 \%$ & $-2.5 \%$ & $-7.6 \%$ & $-4.2 \%$ & $-8.1 \%$ \\
2001 & $4.2 \%$ & & $-1.1 \%$ & $-0.9 \%$ & $-6.5 \%$ & $0.0 \%$ & $-1.3 \%$ & $-6.1 \%$ & $-0.8 \%$ & $-7.4 \%$ \\
2002 & $4.9 \%$ & & $-0.5 \%$ & $-1.7 \%$ & $-5.8 \%$ & $0.4 \%$ & $-1.8 \%$ & $-5.7 \%$ & $-2.6 \%$ & $-7.2 \%$ \\
2003 & $-1.4 \%$ & $-10.1 \%$ & $-0.4 \%$ & $-1.4 \%$ & $-5.5 \%$ & $-1.2 \%$ & $-1.6 \%$ & $-6.0 \%$ & $-2.8 \%$ & $-7.2 \%$ \\
2004 & $-1.2 \%$ & $-2.8 \%$ & $-0.1 \%$ & $-1.1 \%$ & $-5.0 \%$ & $-2.3 \%$ & $-1.1 \%$ & $-6.2 \%$ & $-8.5 \%$ & $-7.0 \%$ \\
2005 & $-0.4 \%$ & $-4.5 \%$ & $0.5 \%$ & $-2.4 \%$ & $-4.3 \%$ & $-1.4 \%$ & $-3.5 \%$ & $-5.7 \%$ & $-8.0 \%$ & $-6.1 \%$ \\
\hline
\end{tabular}

Weighted average of the foreign - home tax differential, weights given by the operating revenues of the subsidiary

Table 5: Average of the foreign-home tax differential $\left(t_{B}-t_{A}\right)$

$$
\text { Leverage }_{i t}=F_{i t-1}^{\prime} \widetilde{\beta}+T_{i t}^{\prime} \gamma+B_{t}^{\prime} \widetilde{\delta}+\alpha_{i}+\varepsilon_{i t},
$$

where $i$ identifies the subsidiary firm and $t$ denotes the year of reference. Following Fan et al. (2003), we include in $F_{i t-1}^{\prime}$ the past values of the ROA, the logarithm of the operating revenues, the $Z$-score index, the ratio between fixed assets over total assets and a dummy variable which equals one if at time $t-1$ the subsidiary generated negative operating profits. ${ }^{17}$ We control

\footnotetext{
${ }^{17} \mathrm{We}$ also considered the inclusion of the past value of working capital, but its estimated effect on the leverage was not significantly different from zero, once controlled for the variables described above.
} 
for business cycle effects by including the PPP per-capita GDP growth rate in the regression. The fiscal variables $T_{i t}$ include the subsidiary $\left(\tau_{B i t}\right)$, its ultimate owner's statutory corporate tax rate $\left(\tau_{\text {Ait }}\right)$ and their interaction $\left(\tau_{\text {Bit }} \times \tau_{\text {Ait }}\right) .{ }^{18}$ Finally, we consider a full set of industry, regional and owner type dummies.

We rationalize the choice of the financial account data $\left(F_{i t-1}\right)$ with the need to control for different factors affecting the access to credit markets and a firm's demand for loans. We therefore include a measure of firm profitability such as ROA (i.e., the ratio EBIT/total assets) because more profitable companies have lower incentives to implement debt policies as they could finance their investments through their own resources. Firms reporting losses have no fiscal incentives for increasing their debts and they might face credit constraints. At the same time, they are likely to demand for more loans. We evaluate which of the two effects is more relevant by including in $F_{i t-1}$ a dummy variable indicating whether companies end up with a loss in the previous fiscal year. Since bankruptcy cost may be lower for larger firms (Warner, 1977; Ang et al., 1982; Pettit and Singer, 1985) we include a measure of firm size (the logarithm of the operating revenue). We also consider the fixed-to-total assets ratio in order to assess to what extent firms' assets structure affects the level of leverage. Indeed, fixed assets are guarantees for creditors and can positively influence a firm's leverage (Myers, 1977; Scott, 1977; Harris and Raviv, 1990). Finally, the Z-score index is included in the regression in order to take into account the credit worthiness of the company (Desai et al. 2004; Fan et al. 2003; Panteghini, 2009).

We estimate equation (12) for the full sample and the subsample of the linked subsidiaries. We provide OLS and fixed effects estimates. ${ }^{19}$ Fixed effects estimates take into account all the (time invariant) unobserved heterogeneity which characterizes firms and its likely correlation with the observed characteristics. They are therefore our preferred estimation strategy, because they provide results which are more robust to the measurement error problem, to the omitted variables problem and to the sample selection issue when we restrict our analysis to the subsample of the linked subsidiaries.

In Table 6 we present the estimates of equation (12). Let us consider the results for the full sample first. OLS and fixed effects estimates provide

\footnotetext{
${ }^{18}$ In order to control for non-linear effects we also tried to introduce the square of the two tax rates. However, this variable was never significant.

${ }^{19}$ Random effects estimates do not differ systematically from fixed effects estimates.
} 


\begin{tabular}{|c|c|c|c|c|}
\hline & \multicolumn{2}{|c|}{ All sample } & \multicolumn{2}{|c|}{ Only linked subsidiaries } \\
\hline & OLS & $\mathrm{FE}$ & OLS & $\mathrm{FE}$ \\
\hline $\begin{array}{l}\text { Ultimate owner } \\
\text { tax rate }\end{array}$ & $\begin{array}{l}-0.37145 \\
(0.38551)\end{array}$ & $\begin{array}{c}0.72553 \\
(0.13313) * * *\end{array}$ & $\begin{array}{c}-0.5613 \\
(0.49839)\end{array}$ & $\begin{array}{c}0.82143 \\
(0.18664) * * *\end{array}$ \\
\hline Subsidiary tax rate & $\begin{array}{l}0.15249 \\
(0.42859)\end{array}$ & $\begin{array}{l}1.03048 \\
(0.15101) * * *\end{array}$ & $\begin{array}{c}-0.30183 \\
(0.52935)\end{array}$ & $\begin{array}{l}0.86809 \\
(0.20520) * * *\end{array}$ \\
\hline UO $*$ Subsidiary tax rate & $\begin{array}{l}0.77003 \\
(1.14799)\end{array}$ & $\begin{array}{l}-1.45838 \\
(0.40132) * * *\end{array}$ & $\begin{array}{l}1.68758 \\
(1.48379)\end{array}$ & $\begin{array}{l}-1.5476 \\
(0.55995) * * *\end{array}$ \\
\hline GDP growth rate & $\begin{array}{l}0.55554 \\
(0.11619) * * *\end{array}$ & $\begin{array}{c}0.4083 \\
(0.05349) * * *\end{array}$ & $\begin{array}{l}0.34128 \\
(0.12505) * * *\end{array}$ & $\begin{array}{l}0.15103 \\
(0.07501) * *\end{array}$ \\
\hline Limited company & $\begin{array}{l}-0.02849 \\
(0.00740) * * *\end{array}$ & & $\begin{array}{l}-0.02519 \\
(0.00984) * *\end{array}$ & \\
\hline Negative profits in t-1 & $\begin{array}{l}0.03483 \\
(0.00508) * * *\end{array}$ & $\begin{array}{l}0.03138 \\
(0.00156) * * *\end{array}$ & $\begin{array}{l}0.03528 \\
(0.00598) * * *\end{array}$ & $\begin{array}{c}0.03088 \\
(0.00229) * * *\end{array}$ \\
\hline $\mathrm{ROA}_{t-1}$ & $\begin{array}{c}-0.0131 \\
(0.009)\end{array}$ & $\begin{array}{l}-0.00478 \\
(0.00104) * * *\end{array}$ & $\begin{array}{c}-0.00718 \\
(0.00525)\end{array}$ & $\begin{array}{l}-0.00152 \\
(0.00102)\end{array}$ \\
\hline $\log \left(\right.$ Operating revenue $\left.{ }_{t-1}\right)$ & $\begin{array}{l}0.00645 \\
(0.00205) * * *\end{array}$ & $\begin{array}{l}0.00707 \\
(0.00084) * * *\end{array}$ & $\begin{array}{l}0.00908 \\
(0.00205) * * *\end{array}$ & $\begin{array}{l}0.00736 \\
(0.00121) * * *\end{array}$ \\
\hline$\left(\frac{\text { Fixed Assets }}{\text { Total Assets }}\right)_{t-1}$ & $\begin{array}{l}-0.07429 \\
(0.01663) * * *\end{array}$ & $\begin{array}{l}0.02642 \\
(0.00519) * * *\end{array}$ & $\begin{array}{l}-0.07606 \\
(0.01765) * * *\end{array}$ & $\begin{array}{c}0.03463 \\
(0.00763) * * *\end{array}$ \\
\hline Zscore $_{t-1} / 1000$ & $\begin{array}{l}-0.00278 \\
(0.00134) * *\end{array}$ & $\begin{array}{l}0.00016 \\
(0.00041)\end{array}$ & $\begin{array}{l}-0.0152 \\
(0.00484) * * *\end{array}$ & $\begin{array}{l}-0.0029 \\
(0.00145) * *\end{array}$ \\
\hline 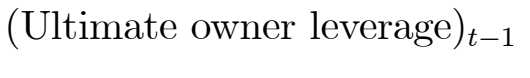 & & & $\begin{array}{l}0.05767 \\
(0.03156) *\end{array}$ & $\begin{array}{l}0.01907 \\
(0.00853) * *\end{array}$ \\
\hline Constant & $\begin{array}{l}0.45703 \\
(0.14307) * * *\end{array}$ & $\begin{array}{l}0.09071 \\
(0.05054) *\end{array}$ & $\begin{array}{l}0.52526 \\
(0.18297) * * *\end{array}$ & $\begin{array}{l}0.13608 \\
(0.06923) * *\end{array}$ \\
\hline Observations & & & & \\
\hline Number of firms & & & & \\
\hline
\end{tabular}

Robust standard errors in parentheses
$*$ significant at $10 \% ; * *$ significant at $5 \% ; * * *$ significant at $1 \%$

Table 6: OLS and fixed effects estimate. OLS standard errors are clustered for foreign - home country correlation. OLS estimates include a full set of industry, country and ultimate owner type dummies. 
different pictures of the effects of past financial accounts on current level of leverage. As expected, previous year firms' profitability, $R O A_{i t-1}$, negatively affect firms' leverage, though the marginal effect, estimated with the fixed effects, is only $1 / 3$ of that estimated with OLS (-0.013 vs. -0.0048). Both OLS and fixed-effect estimates show that firms with a negative operating profit in the previous year have a higher leverage. According to OLS estimates, a higher level of fixed assets reduces leverage, while for the fixed-effect estimates the sign is positive. The fixed-effect estimates of the Z-score parameter are not statistically different from zero, in contrast with the negative effect estimated with OLS. Our estimates suggest that one percentage point more of GDP growth rate increases leverage: this effect ranges from 0.4 to 0.55 p.p.

The parameters related to the tax rates are more precisely estimated with the fixed effects approach, rather than with the OLS. Although the single parameters are not statistically different from zero, we reject the hypothesis that all three of them are jointly equal to zero. Note that, due to the presence of the interaction term, discussed in theoretical section and described by derivatives (10), the marginal variation of the expected value of the subsidiary leverage due to a marginal variation of the subsidiary tax rate is given by:

$$
\frac{\partial E\left[\text { leverage }_{i t} \mid F_{i t-1}, \tau_{B i t}, \tau_{A i t}, B_{t}\right]}{\partial \tau_{B i t}}=\gamma_{\tau_{B}}+\gamma_{\tau_{B} \times \tau_{A}} \tau_{A i t},
$$

where $\tau_{\text {Ait }}$ is the ultimate owner tax rate. Similarly, the marginal effect of the ultimate owner statutory tax rate is given by:

$$
\frac{\partial E\left[\text { leverage }_{i t} \mid F_{i t-1}, \tau_{B i t}, \tau_{A i t}, B_{t}\right]}{\partial \tau_{A i t}}=\gamma_{\tau_{A}}+\gamma_{\tau_{B} \times \tau_{A}} \tau_{B i t},
$$

where $\tau_{\text {Bit }}$ is the subsidiary tax rate. Therefore, the marginal effect of the subsidiary (ultimate owner) tax rate is a linear function of the ultimate owner (subsidiary) tax rate with slope coefficient equal to the parameter of the interaction term (i.e., $\gamma_{\tau_{B} \times \tau_{A}}$ ). It follows that the estimated marginal effects are almost always not significantly different from zero according to the OLS estimates. The corresponding fixed-effect estimates are depicted in Figure 5: an increase in either the subsidiary or the ultimate owner tax rate always has a positive effect on the subsidiary leverage. A change in the subsidiary tax rate always has a greater impact than a change in the tax rate of the parent company. The marginal effect of a tax rate is smaller, the higher the 
level of the other is. At the average level of the ultimate owner tax rate (that is $\left.\tau_{A}=0.35\right)$ the marginal effect of the subsidiary tax rate is equal to 0.52 $(1.03048-1.45838 \times 0.35=0.52)$. This means that 1 p.p. increase in the subsidiary tax rate leads to a 0.52 p.p. increase in its leverage. At the average level of the subsidiary tax rate (that is $\tau_{B}=0.324$ ) the marginal effect of the parent company tax rate is equal to $0.253(0.72553-1.45838 \times 0.324=0.253)$, that is 1 p.p. increase in the ultimate owner tax rate give rise to a 0.25 p.p. increase in its subsidiary's leverage.

By focusing on the subsample of subsidiaries for which the balance sheet information of their ultimate owner are available, we are able to take into account the capital structure of the controlling company. We enrich the original specification of equation (12) by adding the leverage of the ultimate owner at $t-1$ as a control variable. As shown in Table 6, controlling for the leverage of the parent company has proved to be important, but neither its introduction nor the remarkable differences between the subsample considered and the complete set of subsidiaries have had relevant effects on our main parameters: the marginal effects of both the tax rates are similar to the previously discussed case.

Our empirical results can be compared with Mintz and Weichenrieder (2005) for subsidiaries of German companies and Huizinga et al. (2008) for a sample of European subsidiaries. Mintz and Weichenrieder estimated that at average values a one percentage point subsidiary tax rate increase causes leverage to rise by 0.41 percentage points. The size of their estimates is consistent with the corresponding marginal effect we estimate (see the left panel in Figure 5). As they used only subsidiaries of German companies, they were not able to evaluate the effect of a variation of the home country tax rate $\tau_{A}$.

Similarly to our exercise, Huizinga et al. (2008) used a sample of European subsidiaries, but they opted for a different specification. They assumed that the relative weight of the assets of the subsidiary over the total amount of assets of the MNC was given and considered the following specification:

$$
\begin{aligned}
\text { Leverage }_{i t}= & F_{i t-1}^{\prime} \widetilde{\beta}+\gamma_{\tau_{B}} \tau_{B i t}+\gamma_{\tau_{A}}\left[\left(\tau_{B i t}-\tau_{A j t}\right) \rho_{p}+\sum_{j \neq i}^{n}\left(\tau_{B i t}-\tau_{B j t}\right) \rho_{j}\right] \\
& +B_{t}^{\prime} \widetilde{\delta}+\alpha_{i}+\varepsilon_{i t},
\end{aligned}
$$

where $\rho_{i}=A_{i} /\left(A_{p}+\sum_{k} A_{k}\right), k=1, \ldots, n$, identifies the subsidiaries of the $\mathrm{MNC}$ and $p$ the parent company. On the one hand, they considered that 


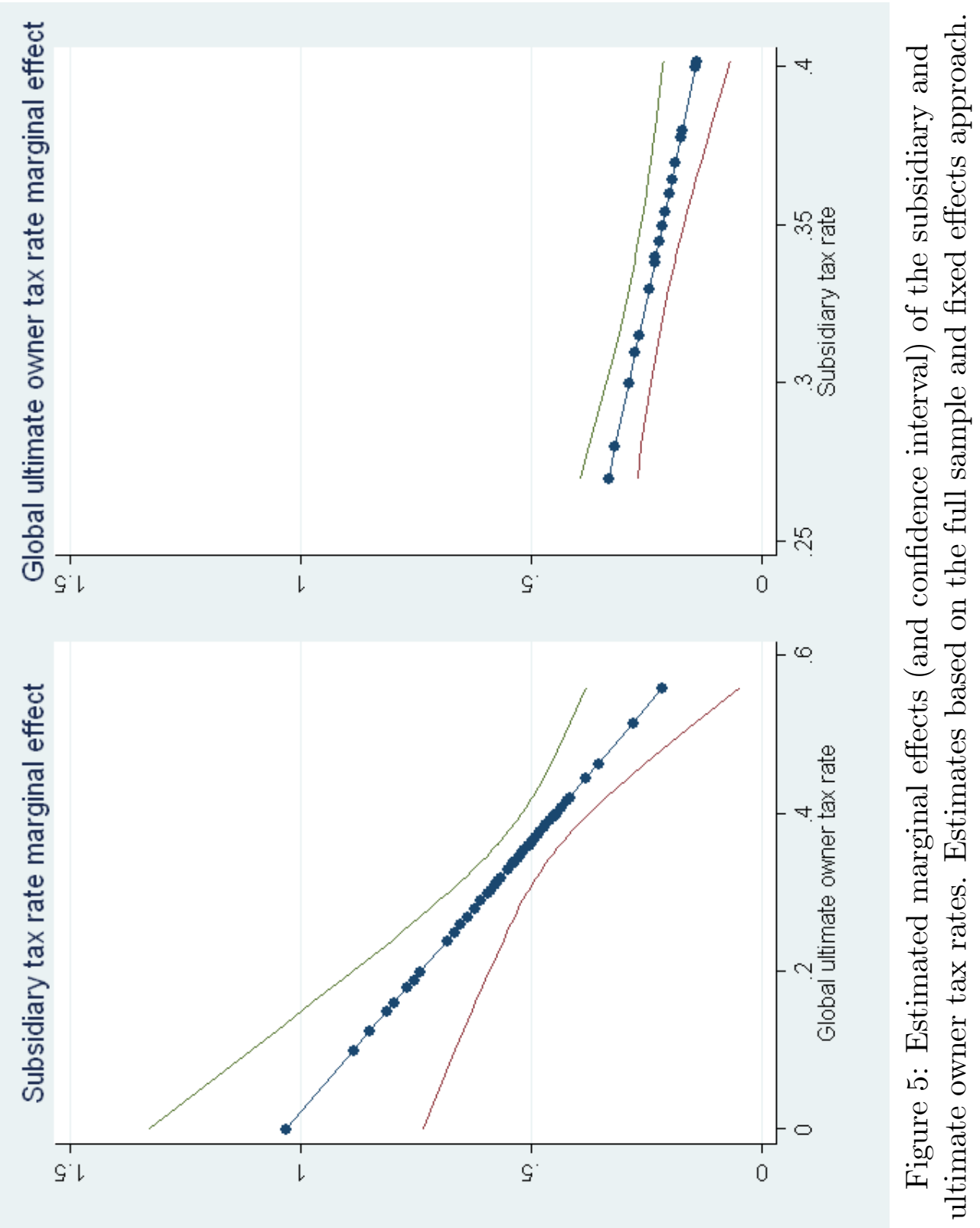


the parent company may have had subsidiaries in more than one foreign country and therefore the leverage of subsidiary $i$ could be also affected by the tax rate faced by the subsidiary $j$. On the other hand, they assumed that the variations in the host country tax rate $\left(\tau_{\text {Ait }}\right)$ and those in the other subsidiaries tax rates $\left(\tau_{B j t}\right)$ had an effect of the same sign on the leverage of subsidiary $i$ (the sign of $\gamma_{\tau_{A}}$ ), while the relative size of such effects was given by the ratio $A_{j} / A_{p}$. The marginal effect of $\tau_{B_{i}}$ on the leverage was given by

$\gamma_{\tau_{B}}+\gamma_{\tau_{A}}\left(\rho_{p}+\sum_{j \neq i}^{n} \rho_{j}\right)<\gamma_{\tau_{B}}+\gamma_{\tau_{A}}$. The effect of $\tau_{B_{j}}$ was equal to $-\gamma_{\tau_{A}} \rho_{j}$ and that of the parent company tax rate $\tau_{A}$ was $-\gamma_{\tau_{A}} \rho_{p}$. Furthermore, they used an overall tax rate (including cross-border dividend taxation). When they considered firm-specific risk they obtained $\widehat{\gamma}_{\tau_{B}}=0.19$ and $\widehat{\gamma}_{\tau_{A}}=0.12$. This implies that a one percentage point foreign tax rate increase causes subsidiary leverage to rise by less than $0.19+0.12=0.31$ percentage points, a value still consistent with our results although on the lower bound of our estimates (see Figure 5). The effect of the home country tax rate $\tau_{A}$ is negative and economically negligible if the asset share of the parent company $\left(\rho_{p}\right)$ is small. However, this result is in sharp contrast with our findings. As we have shown, one percentage point increase of parent company tax rate raises subsidiary's leverage by 0.25 percentage points, when the subsidiary tax rate equals $35 \%$.

\section{Conclusion}

In this article we have introduced a theoretical model, describing a MNC's financial strategies. We have analyzed how debt policy allows multinational groups to shift profits from low-tax to high-tax jurisdictions, when leverage is endogenously determined.

It is worth noting that our model differs from those used in the relevant literature. According to these, a MNC's leverage ratio is exogenously given. In our model, however, both the multinational group's leverage and the optimal percentage of profit shifting are endogenously determined. We have thus shown that tax-motivated activities interact with each other.

This interaction between tax-motivated decisions is a crucial rationale for understanding our empirical results. Using the AMADEUS dataset we have shown that when the parent company tax rate is at $40 \%$, a one percentage point increase in the foreign country tax rate causes a 0.5 percentage points increase in the subsidiary leverage. At the same time, when the subsidiary 
tax rate is $35 \%$ a one percentage point increase in the parent company tax rate causes a 0.25 percentage points rise in of the subsidiary leverage. This latter effect, usually disregarded in the relevant literature, is fully consistent with our theoretical model and suggests that, when the parent company tax rate increases, the positive effect on leverage due to the overall increase in the tax rate prevails on the profit shifting incentives. In this case, an increase in the parent company's tax rate can positively affect a subsidiary's leverage. 


\section{A The derivation of (5)}

Let us first calculate the value of debt, under the assumption that, before default, the lender is tax exempt. ${ }^{20}$ When, in the event of default, the lender becomes shareholder, however, it is subject to the source-based tax levied on the subsidiary. Using dynamic programming, debt can be written as

$$
D(\Pi)= \begin{cases}(1-\widehat{\tau}) \Pi d t+e^{-r d t} \xi[D(\Pi+d \Pi)] & \text { a.d. } \\ C d t+e^{-r d t} \xi[D(\Pi+d \Pi)] & \text { b.d. }\end{cases}
$$

where $\xi$ [.] is the expectation operator, and a.d. and b.d. mean 'after default' and 'before default', respectively. Expanding the RHS of (13), applying Itô's Lemma and rearranging gives

$$
r D(\Pi)=L+\mu \Pi D_{\Pi}(\Pi)+\frac{\sigma^{2}}{2} \Pi^{2} D_{\Pi \Pi}(\Pi),
$$

where $L=(1-\widehat{\tau}) \Pi, C, D_{\Pi}(\Pi) \equiv \frac{\partial D(\Pi)}{\partial \Pi}$ and $D_{\Pi \Pi}(\Pi) \equiv \frac{\partial^{2} D(\Pi)}{\partial \Pi^{2}}$. The general closed-form solution of function (14) is

$$
D(\Pi)= \begin{cases}\frac{(1-\widehat{\tau}) \Pi}{\delta}+\sum_{i=1}^{2} B_{i} \Pi^{\beta_{i}} & \text { a.d. } \\ \frac{C}{r}+\sum_{i=1}^{2} D_{i} \Pi^{\beta_{i}} & \text { b.d. }\end{cases}
$$

where $\delta=r-\mu$ is the so-called dividend yield, $\beta_{1}=\frac{1}{2}-\frac{\mu}{\sigma^{2}}+\sqrt{\left(\frac{\mu}{\sigma^{2}}-\frac{1}{2}\right)^{2}+\frac{2 r}{\sigma^{2}}}>$ 1 and $\beta_{2}=\frac{1}{2}-\frac{\mu}{\sigma^{2}}-\sqrt{\left(\frac{\mu}{\sigma^{2}}-\frac{1}{2}\right)^{2}+\frac{2 r}{\sigma^{2}}}<0$ are the two roots, respectively, of the characteristic equation

$$
\frac{\sigma^{2}}{2} \beta(\beta-1)+\mu \beta-r=0
$$

To calculate $B_{i}$ and $D_{i}$ for $i=1,2$, we need three boundary conditions. First of all, we assume that, whenever $\Pi$ goes to zero, the lender's claim is nil, namely condition $D(0)=0$ holds. This implies that $B_{2}=0$. Secondly, we assume that financial bubbles do not exist. This means that $B_{1}=D_{1}=0 .{ }^{21}$ Thirdly, we must consider that, at point $\Pi=\bar{\Pi}$, the pre-default value of debt

\footnotetext{
${ }^{20}$ It is well-known that effective tax rates on capital income are fairly low. For simplicity we assume that the lender's pre-default tax burden is nil.

${ }^{21}$ For further details on these boundary conditions see Dixit and Pindyck (1994).
} 
must be equal to the post-default one, net of the default cost. Using the two branches of (15) we therefore obtain

$$
\frac{(1-\widehat{\tau}) \bar{\Pi}}{\delta}-\underbrace{\left[\frac{v(1-\widehat{\tau}) \bar{\Pi}}{\delta}\right]}_{\text {default cost }}=\frac{C}{r}+D_{2} \bar{\Pi}^{\beta_{2}} .
$$

Solving for $D_{2}$ gives

$$
D_{2}=\left[\frac{(1-v)(1-\widehat{\tau}) \bar{\Pi}}{\delta}-\frac{C}{r}\right] \bar{\Pi}^{-\beta_{2}} .
$$

We can therefore write the value of debt as follows:

$$
D(\Pi)= \begin{cases}\frac{(1-\widehat{\tau}) \Pi}{\delta} & \text { a.d. }, \\ \frac{C}{r}+\left[\frac{(1-v)(1-\widehat{\tau}) \bar{\Pi}}{\delta}-\frac{C}{r}\right]\left(\frac{\Pi}{\bar{\Pi}}\right)^{\beta_{2}} & \text { b.d. }\end{cases}
$$

Before default, $D(\Pi)$ consists of two terms. The first one, $\frac{C}{r}$, is the present value of a perpetual rent with the discount rate $r$. The second term accounts for any future expected change in profitability caused by default. In particular, the term $\left(\frac{\Pi}{\bar{\Pi}}\right)^{\beta_{2}}$ measures the present value of 1 Euro contingent on the event default. After default, the lender becomes shareholder and her credit is therefore converted into equity. The firm's value is therefore equal to $\frac{(1-\widehat{\tau}) \Pi}{\delta}$.

Let us next calculate the value of equity. Applying dynamic programming we can write

$$
E(\Pi)= \begin{cases}0 & \text { a.d., } \\ \Pi^{N}(\Pi) d t+e^{-r d t} \xi[E(\Pi+d \Pi)] & \text { b.d. }\end{cases}
$$

Expanding the RHS of (17), applying Itô's Lemma, eliminating all terms multiplied by $(d t)^{2}$ and dividing by $d t$ gives:

$$
r E(\Pi)=\Pi^{N}(\Pi)+\mu \Pi E_{\Pi}(\Pi)+\frac{\sigma^{2}}{2} \Pi^{2} E_{\Pi \Pi}(\Pi),
$$

where $E_{\Pi}(\Pi) \equiv \frac{\partial E(\Pi)}{\partial \Pi}$ and $E_{\Pi \Pi}(\Pi) \equiv \frac{\partial^{2} E(\Pi)}{\partial \Pi^{2}}$. Substituting (2) into (18) and solving gives

$$
E(\Pi)= \begin{cases}0 & \text { a.d. }, \\ (1-\widehat{\tau})\left(\frac{\Pi}{\delta}-\frac{C}{r}\right)+\phi(\gamma, n) \frac{C}{r}+\sum_{i=1}^{2} A_{i} \Pi^{\beta_{i}} & \text { b.d. }\end{cases}
$$


Let us next calculate $A_{i}$ with $i=1,2$. In the absence of financial bubbles, we have $A_{1}=0$. Moreover, to calculate $A_{2}$ we let the two branches of (19) meet at point $\Pi=\bar{\Pi}$, thereby obtaining

$$
E(\bar{\Pi})=(1-\widehat{\tau})\left(\frac{\bar{\Pi}}{\delta}-\frac{C}{r}\right)+\phi(\gamma, n) \frac{C}{r}+A_{2} \bar{\Pi}^{\beta_{2}}=0 .
$$

Solving (20) for $A_{2}$ gives

$$
A_{2}=-\left[(1-\widehat{\tau})\left(\frac{\bar{\Pi}}{\delta}-\frac{C}{r}\right)+\phi(\gamma, n) \frac{C}{r}\right] \bar{\Pi}^{-\beta_{2}},
$$

so that the value of equity is equal to:

$$
E(\Pi)= \begin{cases}0 & \text { a.d. } \\ (1-\widehat{\tau})\left(\frac{\Pi}{\delta}-\frac{C}{r}\right)+\phi(\gamma, n) \frac{C}{r} & \\ -\left[(1-\widehat{\tau})\left(\frac{\bar{\Pi}}{\delta}-\frac{C}{r}\right)+\phi(\gamma, n) \frac{C}{r}\right]\left(\frac{\Pi}{\bar{\Pi}}\right)^{\beta_{2}} & \text { b.d. }\end{cases}
$$

Summing (16) and (21) gives the value function (5).

\section{B The MNC's choices}

Let us substitute (4) into (5) and rearrange, so as to obtain:

$$
\begin{aligned}
V(C, \gamma ; \Pi)= & \frac{(1-\widehat{\tau}) \Pi}{\delta}+\frac{[\widehat{\tau}+\phi(\gamma, n)] C}{r}-\left[\frac{v[1-[\widehat{\tau}+\phi(\gamma, n)]]}{\delta}\right. \\
& \left.+\frac{\widehat{\tau}+\phi(\gamma, n)}{r}\right]\left(\frac{1-[\widehat{\tau}+\phi(\gamma, n)]}{1-\widehat{\tau}}\right)^{-\beta_{2}} C^{1-\beta_{2}} \Pi^{\beta_{2}}
\end{aligned}
$$

Differentiating $V(C, \gamma ; \Pi)$ with respect to $C$ and $\gamma$ gives:

$$
\begin{aligned}
\frac{\partial V(C, \gamma ; \Pi)}{\partial C}= & \frac{[\widehat{\tau}+\phi(\gamma, n)]}{r}-\left(1-\beta_{2}\right)\left[\frac{v[1-[\widehat{\tau}+\phi(\gamma, n)]]}{\delta}\right. \\
& \left.+\frac{[\widehat{\tau}+\phi(\gamma, n)]}{r}\right]\left(\frac{1-[\widehat{\tau}+\phi(\gamma, n)]}{1-\widehat{\tau}}\right)^{-\beta_{2}} C^{-\beta_{2}} \Pi^{\beta_{2}}=0,
\end{aligned}
$$

and

$$
\frac{\partial V(C, \gamma ; \Pi)}{\partial \phi(\gamma, n)} \cdot \frac{\partial \phi(\gamma, n)}{\partial \gamma}=0
$$


where

$$
\begin{aligned}
& \frac{\partial V(C, \gamma ; \Pi)}{\partial \phi(\gamma, n)}=\frac{C}{r}-\left(-\frac{v}{\delta}+\frac{1}{r}\right)(1-[\widehat{\tau}+\phi(\gamma, n)])^{-\beta_{2}} C^{1-\beta_{2}}[(1-\widehat{\tau}) \Pi]^{\beta_{2}} \\
& -\left[\frac{v[1-[\widehat{\tau}+\phi(\gamma, n)]]}{\delta}+\frac{[\widehat{\tau}+\phi(\gamma, n)]}{r}\right]\left(-\beta_{2}\right)(1-[\widehat{\tau}+\phi(\gamma, n)])^{-1}(-1)\left[\left(\frac{1-[\widehat{\tau}+\phi(\gamma, n)]}{1-\widehat{\tau}}\right)^{-\beta_{2}} C^{1-\beta_{2}} \Pi^{\beta_{2}}\right] \\
& =\frac{C}{r}-\left(\frac{1-[\widehat{\tau}+\phi(\gamma, n)]}{1-\widehat{\tau}}\right)^{-\beta_{2}} C^{1-\beta_{2}} \Pi^{\beta_{2}}\left\{\left(-\frac{v}{\delta}+\frac{1}{r}\right)\right. \\
& \left.+\beta_{2}\left[\frac{v[1-[\widehat{\tau}+\phi(\gamma, n)]]}{\delta}+\frac{[\widehat{\tau}+\phi(\gamma, n)]}{r}\right](1-[\widehat{\tau}+\phi(\gamma, n)])^{-1}\right\} .
\end{aligned}
$$

Rearranging (23) and (24) one obtains:

$$
\frac{1}{1-\beta_{2}} \frac{\frac{[\widehat{\tau}+\phi(\gamma, n)]}{r}}{\left[\frac{v[1-[\widehat{\tau}+\phi(\gamma, n)]]}{\delta}+\frac{[\widehat{\tau}+\phi(\gamma, n)]}{r}\right]}=\left(\frac{1-[\widehat{\tau}+\phi(\gamma, n)]}{1-\widehat{\tau}}\right)^{-\beta_{2}}\left(\frac{\Pi}{C}\right)^{\beta_{2}}
$$

and

$$
\begin{aligned}
\frac{\partial V(C, \gamma ; \Pi)}{\partial \phi(\gamma, n)} C^{-1}= & \frac{1}{r}-\left(\frac{1-[\widehat{\tau}+\phi(\gamma, n)]}{1-\widehat{\tau}}\right)^{-\beta_{2}}\left(\frac{\Pi}{C}\right)^{\beta_{2}} \\
& \cdot\left\{\left(\frac{1}{r}-\frac{v}{\delta}\right)+\beta_{2}\left[\frac{v[1-[\widehat{\tau}+\phi(\gamma, n)]]}{\delta}+\frac{[\widehat{\tau}+\phi(\gamma, n)]}{r}\right] .\right. \\
& \left.\cdot(1-[\widehat{\tau}+\phi(\gamma, n)])^{-1}\right\} \\
= & \frac{1}{r}-\left(\frac{1-[\widehat{\tau}+\phi(\gamma, n)]}{1-\widehat{\tau}}\right)^{-\beta_{2}}\left(\frac{\Pi}{C}\right)^{\beta_{2}} \\
& \cdot\left\{\left(\frac{1}{r}-\frac{v}{\delta}\right)+\beta_{2} \frac{\left[\frac{v[1-[\widehat{\tau}+\phi(\gamma, n)]]}{\delta}+\frac{[\widehat{\tau}+\phi(\gamma, n)]}{r}\right]}{(1-[\widehat{\tau}+\phi(\gamma, n)])}\right\} .
\end{aligned}
$$

Rearranging gives (7). Since

$$
\frac{1}{1-\beta_{2}} \frac{\frac{[\widehat{\tau}+\phi(\gamma, n)]}{r}}{\left[\frac{v[1-[\widehat{\tau}+\phi(\gamma, n)]]}{\delta}+\frac{[\widehat{\tau}+\phi(\gamma, n)]}{r}\right]}=\left(\frac{1-[\widehat{\tau}+\phi(\gamma, n)]}{1-\widehat{\tau}}\right)^{-\beta_{2}}\left(\frac{\Pi}{C}\right)^{\beta_{2}}<1,
$$


we can rewrite the derivative (25) as follows:

$$
\begin{aligned}
\frac{\partial V(C, \gamma ; \Pi)}{\partial \phi(\gamma, n)} r C^{-1}= & 1-\underbrace{\left\{\frac{1}{1-\beta_{2}} \frac{\frac{[\widehat{\tau}+\phi(\gamma, n)]}{r}}{\left[\frac{v[1-[\widehat{\tau}+\phi(\gamma, n)]]}{\delta}+\frac{[\widehat{\tau}+\phi(\gamma, n)]}{r}\right]}\right\}}_{<1} \\
& \cdot \underbrace{\left\{\left(1-\frac{v r}{\delta}\right)+\beta_{2} \frac{\left[\frac{v r[1-[\widehat{\tau}+\phi(\gamma, n)]]}{\delta}+[\widehat{\tau}+\phi(\gamma, n)]\right]}{(1-[\widehat{\tau}+\phi(\gamma, n)])}\right\}}_{<1}
\end{aligned}
$$

It is easy to show that

$$
\left\{\frac{1}{1-\beta_{2}} \frac{\frac{[\widehat{\tau}+\phi(\gamma, n)]}{r}}{\left[\frac{v[1-[\widehat{\tau}+\phi(\gamma, n)]]}{\delta}+\frac{[\widehat{\tau}+\phi(\gamma, n)]}{r}\right]}\right\}^{-1}>1>\left\{\left(1-\frac{v r}{\delta}\right)+\beta_{2} \frac{\left[\frac{v r[1-[\widehat{\tau}+\phi(\gamma, n)]]}{\delta}+[\widehat{\tau}+\phi(\gamma, n)]\right]}{(1-[\widehat{\tau}+\phi(\gamma, n)])}\right\} .
$$

This means that

$$
\frac{\partial V(C, \gamma ; \Pi)}{\partial \phi(\gamma, n)}>0
$$

and hence,

$$
\frac{\partial V(C, \gamma ; \Pi)}{\partial \phi(\gamma, n)} \cdot \frac{\partial \phi(\gamma, n)}{\partial \gamma} \propto \frac{\partial \phi(\gamma, n)}{\partial \gamma}
$$

We can therefore focus on the term $\frac{\partial \phi(\gamma, n)}{\partial \gamma}$. Given assumption 7, we can rewrite the MNC's income shifting problem as follows

$$
\gamma^{*}=\arg \max _{\gamma} \phi(\gamma, n)
$$

Solving (26) we obtain (8). 


\section{Comparative statics}

In this Appendix we show that both $\frac{\partial C^{*}}{\partial \phi\left(\gamma^{*}, n\right)}$ and $\frac{\partial C^{*}}{\partial \widehat{\tau}}$ are positive. Taking the log of (7) one obtains:

$$
\begin{aligned}
\log C^{*}= & -\frac{1}{\beta_{2}}\left\{\log \left(\frac{1}{1-\beta_{2}}\right)+\log 1-\log \left[\frac{v r}{\delta}\left[\frac{1}{\widehat{\tau}+\phi\left(\gamma^{*}, n\right)}-1\right]+1\right]\right\} \\
& +\log \left(\frac{1-\widehat{\tau}}{1-\widehat{\tau}+\phi\left(\gamma^{*}, n\right)}\right)+\log \Pi \\
= & {\left[-\frac{1}{\beta_{2}} \log \left(\frac{1}{1-\beta_{2}}\right)+\log \Pi\right]+\frac{1}{\beta_{2}} \log \left[\frac{v r}{\delta}\left[\frac{1}{\widehat{\tau}+\phi\left(\gamma^{*}, n\right)}-1\right]+1\right] } \\
& +\log (1-\widehat{\tau})-\log \left[1-\left[\widehat{\tau}+\phi\left(\gamma^{*}, n\right)\right]\right] .
\end{aligned}
$$

Differentiating $\log C^{*}$ with respect to $\phi\left(\gamma^{*}, n\right)$ gives:

$$
\begin{aligned}
& \frac{1}{C^{*}} \frac{\partial C^{*}}{\partial \phi\left(\gamma^{*}, n\right)}=\frac{1}{\beta_{2}} \frac{\left[-\frac{v r}{\delta}\left[\widehat{\tau}+\phi\left(\gamma^{*}, n\right)\right]^{-2}\right]}{\frac{v r}{\delta}\left[\frac{1}{\widehat{\tau}+\phi\left(\gamma^{*}, n\right)}-1\right]+1}+\frac{1}{1-\left[\widehat{\tau}+\phi\left(\gamma^{*}, n\right)\right]}
\end{aligned}
$$

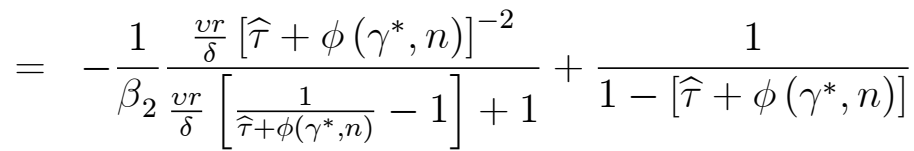

$$
\begin{aligned}
& >0 \text {. }
\end{aligned}
$$

Differentiating $\log C^{*}$ with respect to $\widehat{\tau}$ gives:

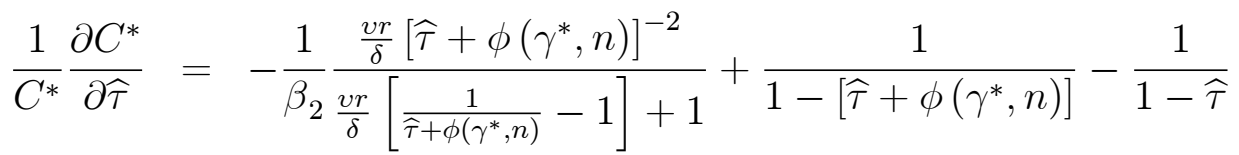

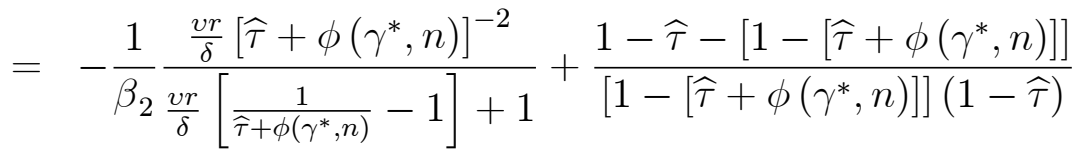

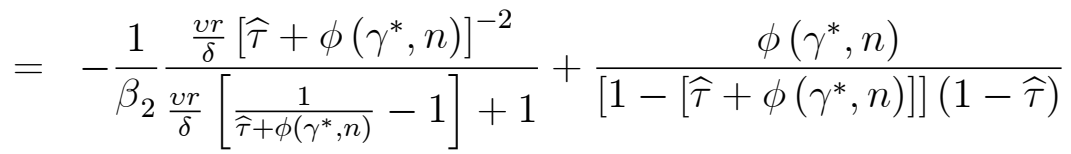

$$
\begin{aligned}
& >0 \text {. }
\end{aligned}
$$




\section{The subsidiary's value}

As shown in (2), the subsidiary's after-tax profit is

$$
\Pi_{S}^{N}(\Pi)=\left(1-\tau_{B}\right)\left[(1-\chi)\left(\Pi-C^{*}\right)+\gamma^{*} C^{*}\right] .
$$

Using (27) and applying dynamic programming we can calculate the subsidiary's equity value:

$$
E_{S}(\Pi)= \begin{cases}0 & \text { a.d. } \\ \left(1-\tau_{B}\right)\left[(1-\chi)\left(\frac{\Pi}{\delta}-\frac{C^{*}}{r}\right)+\frac{\gamma^{*} C^{*}}{r}\right]+\sum_{i=1}^{2} G_{i} \Pi^{\beta_{i}} & \text { b.d. }\end{cases}
$$

As usual, in the absence of financial bubbles, we have $G_{1}=0$. To find $G_{2}$ we apply the following boundary condition, which states that, at point $\bar{\Pi}$, the subsidiary's equity value is nil:

$$
E_{S}(\bar{\Pi})=\left(1-\tau_{B}\right)\left[(1-\chi)\left(\frac{\bar{\Pi}}{\delta}-\frac{C^{*}}{r}\right)+\frac{\gamma^{*} C^{*}}{r}\right]+G_{2} \bar{\Pi}^{\beta_{2}}=0 .
$$

We therefore obtain

$$
G_{2}=-\left(1-\tau_{B}\right)\left[(1-\chi)\left(\frac{\bar{\Pi}}{\delta}-\frac{C^{*}}{r}\right)+\frac{\gamma^{*} C^{*}}{r}\right] \bar{\Pi}^{-\beta_{2}}
$$

so that the value of equity is equal to:

$$
E_{S}(\Pi)= \begin{cases}0 & \text { a.d. } \\ & \left(1-\tau_{B}\right)\left\{(1-\chi)\left[\left(\frac{\Pi}{\delta}-\frac{C^{*}}{r}\right)-\left(\frac{\bar{\Pi}}{\delta}-\frac{C^{*}}{r}\right)\left(\frac{\Pi}{\bar{\Pi}}\right)^{\beta_{2}}\right]\right. \\ & \left.+\left[1-\left(\frac{\Pi}{\bar{\Pi}}\right)^{\beta_{2}}\right] \frac{\gamma^{*} C^{*}}{r}\right\}\end{cases}
$$




\section{References}

[1] Altman, E. (2002), Predicting Financial Distress of Companies: Revisiting the Z-Score and Zeta Models, New York University W.P., pages.stern.nyu.edu/ ealtman/zscore.pdf.

[2] Altshuler, R. and J. Mintz (1995), U.S. Interest-Allocation Rules: Effects and Policy, International Tax and Public Finance, 2, pp. 7-35.

[3] Altshuler, R. and H. Grubert (2003), Repatriation Taxes, Repatriation Strategies and Multinational Financial Policy, Journal of Public Economics, 87, pp. 73-107.

[4] Ang, J. S., Chua J.H. and J.J. McConnell (1982), The Administrative Costs of Corporate Bankruptcy: A Note, Journal of Finance, American Finance Association, 37, pp. 219-226.

[5] Brennan M.J. and E.S. Schwartz (1977), Convertible Bonds: Valuation and Optimal Strategies for Call and Conversion, Journal of Finance, 32, pp. 1699-1715.

[6] Buettner, T., M. Overesch, U. Schreiber and G. Wamser (2006a), The Impact of Thin-Capitalization Rules on Multinationals' Financing and Investment Decisions, CESifo Working Paper Series No. 1817, ZEW Discussion Paper No. 06-68

[7] Buettner, T., M. Overesch, U. Schreiber and G. Wamser (2006b), Taxation and Capital Structure Choice - Evidence from a Panel of German Multinationals, ZEW Discussion Paper No. 06-067.

[8] Buettner, T. and G. Wamser (2007), Intercompany Loans and Profit Shifting - Evidence from Company-Level Data, CESifo Working Paper Series No. 1959.

[9] Collins, J.H. and D.A. Shackelford (1992), Foreign Tax Credit Limitations and Preferred Stock Issuances, Journal of Accounting Research, 30, pp. 103-124.

[10] Desai, M.A. (2003), The Divergence between Book Income and Tax Income, Tax Policy and the Economy, 17, pp. 169-206, Cambridge: MIT Press for the National Bureau of Economic Research. 
[11] Desai, M.A., F.C. Foley, and J.R. Jr. Hines (2004), A Multinational Perspective on Capital Structure Choice and Internal Capital Markets, Journal of Finance, 59, pp. 2451-2487.

[12] Desai, M.A. (2005), The Degradation of Reported Corporate Profits, Journal of Economic Perspectives, 12, pp. 171-192.

[13] Desai, M.A., F.C. Foley, and J.R. Jr. Hines (2006), Capital Structure with Risky Foreign Investment, NBER W.P. No. 12276.

[14] Devereux M.P. (2007), The Impact of Taxation on the Location of Capital, Firms and Profit: a Survey of Empirical Evidence, Oxford University Centre for Business Taxation Saïd Business School, W.P. 07/02.

[15] Dixit, A.K. and R.S. Pindyck (1994), Investment under Uncertainty, Princeton University Press.

[16] Dixit, A.K. and R.S. Pindyck (1999), Expandability, Reversibility, and Optimal Capacity Choice, in Project Flexibility, Agency, and Competition, M.J. Brennan and L. Trigeorgis (Eds.), Oxford University Press.

[17] Fan, J.P.H., S. Titman, and G.J. Twite (2003), An International Comparison of Capital Structure and Debt Maturity Choices, AFA 2005 Philadelphia Meetings, EFA 2003 Annual Conference Paper No. 769.

[18] Froot, K.A. and J.R. Hines (1995), Interest Allocation Rules, Financing Patterns, and the Operations of U.S. Multinationals, in Feldstein, M., J.R. Hines and R.G. Hubbard (eds.), The Effects of Taxation on Multinational Corporations, University of Chicago Press.

[19] Goldstein, R., N. Ju and H. Leland (2001), An EBIT-Based Model of Dynamic Capital Structure, Journal of Business, 74, pp. 483-512.

[20] Graham, J.R. and A.L. Tucker (2005), Tax Shelters and Corporate Debt Policy, mimeo.

[21] Harris M. and A. Raviv (1990), Capital Structure and the Informational Role of Debt, The Journal of Finance, 45, pp. 321-349.

[22] Hines, J.R. Jr. (1999), Lessons from Behavioral Responses to International Taxation, National Tax Journal, 52, pp. 304-322. 
[23] Huizinga, H., L. Laeven, and G. Nicodeme (2008), Capital Structure and International Debt Shifting, Journal of Financial Economics, 88, pp. 80-118.

[24] Jog V.M. and J. Tang (2001), Tax Reforms, Debt Shifting and Tax Revenues: Multinational Corporations in Canada, International Tax and Public Finance, 8, pp. 5-25.

[25] Leland, H.E. (1994), Corporate Debt Value, Bond Covenants, and Optimal Capital Structure, Journal of Finance, 49, pp. 1213-1252.

[26] Mills, L.F. and K.J. Newberry (2004), Do Foreign Multinational's Tax Incentives Influence Their U.S. Income Reporting and Debt Policy?, National Tax Journal, 57, pp. 89-107.

[27] Mintz, J. (2000), Reforming the Tax Cut Agenda, Canadian Tax Journal, 48, pp. 689-709.

[28] Mintz, J. and M. Smart (2004), Income Shifting, Investment, and Tax Competition: Theory and Evidence from Provincial Taxation in Canada, Journal of Public Economics, 88, pp. 1149-1168.

[29] Mintz, J. and A.J. Weichenrieder (2005), Taxation and the Financial Structure of German Outbound FDI, CESifo Working Paper No. 1612.

[30] Myers, S.C. (1977), Determinants of Corporate Borrowing, Journal of Financial Economics, 5, pp. 147-175.

[31] Newberry, K. and D.S. Dhaliwahl (2001), Cross-Jurisdictional Income Shifting by U.S. Multinationals: Evidence from International Bond Offerings, Journal of Accounting Research, 39, pp. 643-662.

[32] Panteghini, P.M. (2006), S-Based Taxation under Default Risk, Journal of Public Economics, 90, pp. 1923-1937.

[33] Panteghini, P.M. (2007), Corporate Taxation in a Dynamic World, Springer.

[34] Panteghini, P.M. (2009), The Capital Structure of Multinational Companies under Tax Competition, International Tax and Public Finance, 16, pp. 59-81. 
[35] Pettit, R.R. and R.F. Singer, (1985), Small Business Finance: A Research Agenda, Financial Management, 14 (3), pp.47-60.

[36] Scott, J.H. Jr. (1977), Bankruptcy, Secured Debt, and Optimal Capital Structure, Journal of Finance, 32, pp. 1-19.

[37] Smith, C.W. Jr. and J.B. Warner (1979), On Financial Contracting An Analysis of Bond Covenants, Journal of Financial Economics, 7, pp. 117-161.

[38] Warner, J.B. (1977), Bankruptcy Costs: Some Evidence, Journal of Finance, 32, Papers and Proceedings of the Thirty-Fifth Annual Meeting of the American Finance Association, pp. 337-347. 


\section{CESifo Working Paper Series}

for full list see www.cesifo-group.org/wp

(address: Poschingerstr. 5, 81679 Munich, Germany, office@cesifo.de)

2921 Mariagiovanna Baccara, Allan Collard-Wexler, Leonardo Felli and Leeat Yariv, Gender and Racial Biases: Evidence from Child Adoption, January 2010

2922 Kurt R. Brekke, Roberto Cellini, Luigi Siciliani and Odd Rune Straume, Competition and Quality in Regulated Markets with Sluggish Demand, January 2010

2923 Stefan Bauernschuster, Oliver Falck and Niels Große, Can Competition Spoil Reciprocity? - A Laboratory Experiment, January 2010

2924 Jerome L. Stein, A Critique of the Literature on the US Financial Debt Crisis, January 2010

2925 Erkki Koskela and Jan König, Profit Sharing, Wage Formation and Flexible Outsourcing under Labor Market Imperfection, January 2010

2926 Gabriella Legrenzi and Costas Milas, Spend-and-Tax Adjustments and the Sustainability of the Government's Intertemporal Budget Constraint, January 2010

2927 Piero Gottardi, Jean Marc Tallon and Paolo Ghirardato, Flexible Contracts, January 2010

2928 Gebhard Kirchgässner and Jürgen Wolters, The Role of Monetary Aggregates in the Policy Analysis of the Swiss National Bank, January 2010

2929 J. Trent Alexander, Michael Davern and Betsey Stevenson, Inaccurate Age and Sex Data in the Census PUMS Files: Evidence and Implications, January 2010

2930 Stefan Krasa and Mattias K. Polborn, Competition between Specialized Candidates, January 2010

2931 Yin-Wong Cheung and Xingwang Qian, Capital Flight: China's Experience, January 2010

2932 Thomas Hemmelgarn and Gaetan Nicodeme, The 2008 Financial Crisis and Taxation Policy, January 2010

2933 Marco Faravelli, Oliver Kirchkamp and Helmut Rainer, Social Welfare versus Inequality Concerns in an Incomplete Contract Experiment, January 2010

2934 Mohamed El Hedi Arouri and Christophe Rault, Oil Prices and Stock Markets: What Drives what in the Gulf Corporation Council Countries?, January 2010

2935 Wolfgang Lechthaler, Christian Merkl and Dennis J. Snower, Monetary Persistence and the Labor Market: A New Perspective, January 2010 
2936 Klaus Abberger and Wolfgang Nierhaus, Markov-Switching and the Ifo Business Climate: The Ifo Business Cycle Traffic Lights, January 2010

2937 Mark Armstrong and Steffen Huck, Behavioral Economics as Applied to Firms: A Primer, February 2010

2938 Guglielmo Maria Caporale and Alessandro Girardi, Price Formation on the EuroMTS Platform, February 2010

2939 Hans Gersbach, Democratic Provision of Divisible Public Goods, February 2010

2940 Adam Isen and Betsey Stevenson, Women's Education and Family Behavior: Trends in Marriage, Divorce and Fertility, February 2010

2941 Peter Debaere, Holger Görg and Horst Raff, Greasing the Wheels of International Commerce: How Services Facilitate Firms' International Sourcing, February 2010

2942 Emanuele Forlani, Competition in the Service Sector and the Performances of Manufacturing Firms: Does Liberalization Matter?, February 2010

2943 James M. Malcomson, Do Managers with Limited Liability Take More Risky Decisions? An Information Acquisition Model, February 2010

2944 Florian Englmaier and Steve Leider, Gift Exchange in the Lab - It is not (only) how much you give ..., February 2010

2945 Andrea Bassanini and Giorgio Brunello, Barriers to Entry, Deregulation and Workplace Training: A Theoretical Model with Evidence from Europe, February 2010

2946 Jan-Emmanuel De Neve, James H. Fowler and Bruno S. Frey, Genes, Economics, and Happiness, February 2010

2947 Camille Cornand and Frank Heinemann, Measuring Agents' Reaction to Private and Public Information in Games with Strategic Complementarities, February 2010

2948 Roel Beetsma and Massimo Giuliodori, Discretionary Fiscal Policy: Review and Estimates for the EU, February 2010

2949 Agnieszka Markiewicz, Monetary Policy, Model Uncertainty and Exchange Rate Volatility, February 2010

2950 Hans Dewachter and Leonardo Iania, An Extended Macro-Finance Model with Financial Factors, February 2010

2951 Helmuth Cremer, Philippe De Donder and Pierre Pestieau, Education and Social Mobility, February 2010

2952 Zuzana Brixiová and Balázs Égert, Modeling Institutions, Start-Ups and Productivity during Transition, February 2010 
2953 Roland Strausz, The Political Economy of Regulatory Risk, February 2010

2954 Sanjay Jain, Sumon Majumdar and Sharun W. Mukand, Workers without Borders? Culture, Migration and the Political Limits to Globalization, February 2010

2955 Andreas Irmen, Steady-State Growth and the Elasticity of Substitution, February 2010

2956 Bengt-Arne Wickström, The Optimal Babel - An Economic Framework for the Analysis of Dynamic Language Rights, February 2010

2957 Stefan Bauernschuster and Helmut Rainer, From Politics to the Family: How Sex-Role Attitudes Keep on Diverging in Reunified Germany, February 2010

2958 Patricia Funk and Christina Gathmann, How do Electoral Systems Affect Fiscal Policy? Evidence from State and Local Governments, 1890 to 2005, February 2010

2959 Betsey Stevenson, Beyond the Classroom: Using Title IX to Measure the Return to High School Sports, February 2010

2960 R. Quentin Grafton, Tom Kompas and Ngo Van Long, Biofuels Subsidies and the Green Paradox, February 2010

2961 Oliver Falck, Stephan Heblich, Alfred Lameli and Jens Suedekum, Dialects, Cultural Identity, and Economic Exchange, February 2010

2962 Bård Harstad, The Dynamics of Climate Agreements, February 2010

2963 Frederick van der Ploeg and Cees Withagen, Is There Really a Green Paradox?, February 2010

2964 Ingo Vogelsang, Incentive Regulation, Investments and Technological Change, February 2010

2965 Jan C. van Ours and Lenny Stoeldraijer, Age, Wage and Productivity, February 2010

2966 Michael Hoel, Climate Change and Carbon Tax Expectations, February 2010

2967 Tommaso Nannicini and Roberto Ricciuti, Autocratic Transitions and Growth, February 2010

2968 Sebastian Brauer and Frank Westermann, A Note on the Time Series Measure of Conservatism, February 2010

2969 Wolfram F. Richter, Efficient Education Policy - A Second-Order Elasticity Rule, February 2010

2970 Tomer Blumkin, Yoram Margalioth and Efraim Sadka, Taxing Children: The Redistributive Role of Child Benefits - Revisited, February 2010 
2971 Chang Woon Nam and Georg Wamser, Application of Regionally Varying Additionality Degrees in the Practice of EU Cohesion Policy, February 2010

2972 Ali Bayar, Frédéric Dramais, Cristina Mohora, Masudi Opese and Bram Smeets, Modeling Russia for Climate Change Issues, February 2010

2973 Magnus Söderberg, Informal Benchmarks as a Source of Regulatory Threat in Unregulated Utility Sectors, March 2010

2974 Piotr Wdowiński and Marta Malecka, Asymmetry in Volatility: A Comparison of Developed and Transition Stock Markets, March 2010

2975 Frans van Winden, Michal Krawczyk and Astrid Hopfensitz, Investment, Resolution of Risk, and the Role of Affect, March 2010

2976 Hyun-Ju Koh and Nadine Riedel, Do Governments Tax Agglomeration Rents?, March 2010

2977 Johann K. Brunner and Susanne Pech, Optimum Taxation of Bequests in a Model with Initial Wealth, March 2010

2978 Guglielmo Maria Caporale and Nicola Spagnolo, Stock Market Integration between three CEECs, Russia and the UK, March 2010

2979 Florian Englmaier, Ales Filipi and Ravi Singh, Incentives, Reputation and the Allocation of Authority, March 2010

2980 Konstantinos Angelopoulos, George Economides and Apostolis Philippopoulos, What is the Best Environmental Policy? Taxes, Permits and Rules under Economic and Environmental Uncertainty, March 2010

2981 Frederick van der Ploeg, Rapacious Resource Depletion, Excessive Investment and Insecure Property Rights, March 2010

2982 Wolfram F. Richter and Christoph Braun, Efficient Subsidization of Human Capital Accumulation with Overlapping Generations and Endogenous Growth, March 2010

2983 Francesco Cinnirella, Marc Piopiunik and Joachim Winter, Why Does Height Matter for Educational Attainment? Evidence from German Pre-Teen Children, March 2010

2984 Bernard Van Praag, Well-being Inequality and Reference Groups - An Agenda for New Research, March 2010

2985 Francesca Barion, Raffaele Miniaci, Paolo M. Panteghini and Maria Laura Parisi, Profit Shifting by Debt Financing in Europe, March 2010 